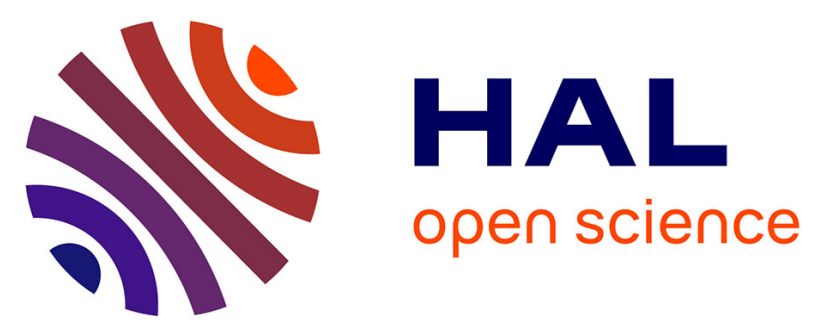

\title{
Late Paleozoic paleogeographic reconstruction of Western Central Asia based upon paleomagnetic data and its geodynamic implications
}

Flavien Choulet, Yan Chen, Bo Wang, Michel Faure, Dominique Cluzel, Jacques Charvet, Wei Lin, Bei Xu

\section{To cite this version:}

Flavien Choulet, Yan Chen, Bo Wang, Michel Faure, Dominique Cluzel, et al.. Late Paleozoic paleogeographic reconstruction of Western Central Asia based upon paleomagnetic data and its geodynamic implications. Journal of Southeast Asian earth sciences, 2011, 42 (5), pp.867-884. 10.1016/j.jseaes.2010.07.011 . insu-00509114

\section{HAL Id: insu-00509114 \\ https://hal-insu.archives-ouvertes.fr/insu-00509114}

Submitted on 8 Sep 2010

HAL is a multi-disciplinary open access archive for the deposit and dissemination of scientific research documents, whether they are published or not. The documents may come from teaching and research institutions in France or abroad, or from public or private research centers.
L'archive ouverte pluridisciplinaire HAL, est destinée au dépôt et à la diffusion de documents scientifiques de niveau recherche, publiés ou non, émanant des établissements d'enseignement et de recherche français ou étrangers, des laboratoires publics ou privés. 


\title{
Late Paleozoic paleogeographic reconstruction of Western Central Asia based upon paleomagnetic data and its geodynamic implications
}

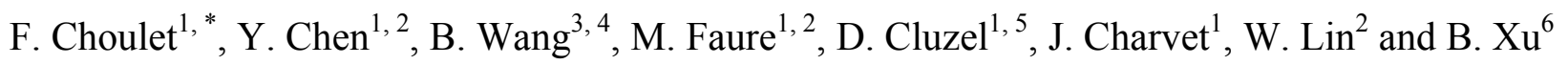

1. Université d'Orléans, CNRS/INSU, Institut des Sciences de la Terre d'Orléans - UMR 6113, France

2. Institute of Geology and Geophysics, Chinese Academy of Sciences, Beijing, China

${ }^{3 .}$ Department of Earth Sciences, Nanjing University, Nanjing, China

4. Institute of Earth Sciences, Academia Sinica, Taipei

5. Université de la Nouvelle Calédonie, EA 3325-PPME.

6. School of Earth and Space Sciences, Peking University, Beijing, China

*: corresponding author, address: UMR 6113 - CNRS/Université d'Orléans, 1A, rue de la Férollerie, F45071 ORLEANS CEDEX 2, Tel. : +33 2384925 73, Fax. : +332 386364 88, Email: flavien.choulet@univ-orleans.fr

\begin{abstract}
Carboniferous to Permian volcanoclastic rocks have been collected from South Junggar and West Junggar. Primary magnetizations have been observed from the characteristic components of 10 sites of Early Permian $\left(\mathrm{P}_{1}\right)$ and Late Pemian $\left(\mathrm{P}_{2}\right)$ red beds of South Junggar area. The 14 Early Carboniferous sites from West Junggar Mountains expose post-folding secondary magnetizations and according to their spatial distribution, 9 remagnetized sites are related to Late Carboniferous Early Permian granite emplacement whereas 5 sites are located at the vicinity of Late Permian mafic dykes.
\end{abstract}


Two new paleomagnetic poles have been consequently calculated for the periods of $\mathrm{P}_{1}$ at $79.5^{\circ} \mathrm{N}, 36.6^{\circ} \mathrm{E}$ and of $\mathrm{P}_{2}$ at $60.4^{\circ} \mathrm{N}, 4.7^{\circ} \mathrm{E}$, with $\mathrm{A}_{95}$ of $6.8^{\circ}$ and $5.4^{\circ}$, respectively. They yield two paleomagnetic poles at $65.3^{\circ} \mathrm{N}, 329.7^{\circ} \mathrm{E}$ with $\mathrm{A}_{95}$ of 6.3 and $64.8^{\circ} \mathrm{N}, 179.5^{\circ} \mathrm{E}$ with $\mathrm{A}_{95}$ of $6.9^{\circ}$ respectively.

Compilation of available data shows stationary and consistent poles for South Junggar area during the Carboniferous and Permian whereas NW Junggar underwent a significant anticlockwise rotation between the Late Carboniferous-Early Permian and the Late Permian, indicating that Junggar was not a rigid block up to the end of the Paleozoic. West Junggar and South Junggar may have experienced contrasting tectonic evolutions.

Comparisons of Late Paleozoic poles of Central Asia blocks show: (1) counter clockwise rotation of West Junggar with respect to Siberia, contrasting with the clockwise rotation of North Kazakhstan with respect to Siberia, (2) no significant movements between West Junggar, North Kazakhstan and Siberia since Late Permian, indicating that they were rigidly welded since that time, and (3) anticlockwise rotations of Tarim, Yili and South Junggar with respect to the welded Siberia-Kazakhstan-West Junggar block. Such rotations may have been accommodated by Late Permian to Early Triassic strike-slip faults with an estimation of the displacements of $1570 \pm 280$ $\mathrm{km}$ along the Irtysh-Gornotsaev Shear Zone, $410 \pm 380 \mathrm{~km}$ along the Nikolaiev-Nalati Tectonic Line and $490 \pm 250 \mathrm{~km}$ along the Chingiz-Alakol-North Tian Shan Fault since Late Permian time.

Keywords: CAOB, Junggar, paleomagnetism, strike-slip faults, Tian Shan, Late Paleozoic 


\section{Introduction}

Paleozoic continental growth in Central Asia results from successive accretion, collision and collage in a huge orogen, called the Central Asian Orogenic Belt (CAOB) which extends from the Urals to the Pacific Ocean between the main continents of Baltica, Siberia, Tarim and North China (Figs. 1a and 1b). On the basis of observation in the western part of the CAOB, Sengör et al., (1993) and Sengör and Natal'in (1996) proposed a model of collage invoking a single long-lived subduction along the Kipchak Arc. They emphasized the role of strike-slip faulting that duplicated the Kipchak Arc. Regional studies provided new data on the accretion and accretion processes in Chinese Tian Shan (e.g. Charvet et al., 2007), Kazakhstan and Kirghizstan (e.g. Windley et al., 2007), Altai (e.g. Xiao et al., 2004) and Mongolia (e.g. Badarch et al., 2002; Windley et al., 2007). These new data do not agree with the Kipchak collage model. Alternative models with multiple subductions of several oceanic basins, island arcs and microcontinents, widely distributed in time and space, similar to the present setting of Southwest Pacific, have been proposed (Xiao et al., 2004; Windley et al., 2007).

Recent paleomagnetic studies also documented a northward drift of the Kazakh terranes during Early Paleozoic accretion (Bazhenov et al., 2003). Successive accretions led to the formation of the Kazakhstan microcontinent (Degtyarev et al., 2007). Along its margin, the Late Paleozoic subduction of the Junggar Ocean is associated with the emplacement of a magmatic arc and an accretionary wedge. The current horseshoe shape of the Kazakhstan (Fig. 1a) results from Devonian to Permian oroclinal bending (Collins et al., 2003; Levashova et al., 2003a, b; 2007; 2009; Van der Voo et al., 2006; Abrajevitch et al., 2007, 2008). The clockwise rotation of its northern limb with respect to its southern one would be responsible for the closure of the Junggar Ocean.

Central Asia underwent a final stage of collage, accommodated by transcurrent deformation (Fig. 1a; Burtman, 1975, 1980; Yin and Nie, 1996; Laurent-Charvet et al., 2003; Buslov et al., 2004; Van der Voo et al., 2006; Wang et al., 2007) coeval with magmatism, leading to world-class 
economic mineral deposits (Yakubchuk, 2004). The origin of the Carboniferous to Permian magmatism has been well constrained by geochemical and geochronological studies (e.g. Jahn et al., 2000; Chen and Jahn, 2004). Although chronological and kinematic studies are available, the amount of displacement along these strike-slip faults and thus the Late Paleozoic paleogeography remains controversial or even unknown. However, recent studies have suggested that the displacement between Late Carboniferous and Late Permian interval can reach several hundreds of kilometers in the Chinese North Tian Shan and more than one thousand kilometers in Altai (Wang et al., 2007). Wang et al. (2007) also considered that the present geometric framework was principally acquired in the Late Permian with only limited Mesozoic motions and a Cenozoic reactivation due to the Indian Collision (Avouac et al., 1993; Chen et al., 1993).

Junggar is a triangular-shaped area surrounded by three belts, with different orientations of verging and accretionary events (e.g. Charvet et al., 2007; Windley et al., 2007; Xiao et al. 2008). The Junggar basin is enclosed between Kazakhstan (west Junggar mountains), Siberia (Altai) and Tian Shan. Due to its location, Junggar is a key area for understanding the final amalgamation of Western Central Asia. Until now, Junggar and its surrounding belts have been regarded as a rigid block and no comparison between these diachronous surrounding belts have been attempted. Thus a paleomagnetic study has been performed in the southern and western borders of the Junggar Basin. This study is an attempt to estimate the Late Paleozoic relative motions between these belts, and also with respect to other units of Central Asia. Another aim of this work is to propose a tentative paleogeographic reconstruction during the Late to Post-orogenic processes of the western part of Central Asia.

\section{Geological setting and paleomagnetic sampling}


Northwestern China consists of several mountain ranges (Tian Shan, Altai, West Junggar Mountains) and sedimentary basins (Yili, Tarim and Junggar). The Junggar area can be simplified as a triangle-shaped sedimentary basin surrounded by Paleozoic orogenic belts (Fig. 1b).

\subsection{The Junggar basin}

Bordered by the Tian Shan range in the south, the Altai in the northeast and the West Junggar mountains in the northwest, the Junggar Basin is filled by Permian to Quaternary sedimentary series overlying an unknown basement, the nature of which is a matter of speculation (e.g. Lawrence, 1990). Based on the sedimentary record along its border, Carroll et al. (1990) suggested a trapped oceanic basin. Hsü (1988) also proposed an oceanic nature of the Junggar crust, but in a back-arc context. However, recent geophysical studies indicated that the thickness of the crust attains to 40 km, suggesting a continental character. Furthermore, recent drillings have encountered schist and volcanic-arc rocks (Ma H.D., personal communication), which question the trapped oceanic crust hypothesis, and argue for the existence of accreted terranes below the Junggar basin. The thick sedimentation started accumulating with Permian marine sandstone mainly derived from the erosion of underlying terranes. Sedimentation changed upwards into lacustrine deposits with several coal lenses and a large amount of oil-bearing material. The deformation, limited to the basin border, along active faults such as the Uhre Thrust is due to intracontinental orogenies.

\subsection{North Tian Shan}

The southern border of the Junggar Basin is in contact with North Tian Shan (Fig. 2), which consists of a Devonian to Carboniferous accretionary complex and a volcanic arc, largely exposed in the Bogda Shan (e.g. Wang et al., 2006; Charvet et al., 2007). Accreted rocks are coarse and finegrained turbidite, associated with an ophiolitic mélange. North-verging folds and top-to-the north kinematic criteria observed in these series argue for a deformation associated with a south-dipping subduction (Wang et al., 2006). Superimposed Permian dextral strike-slip faults affected the 
accretionary complex and the magmatic arc as well (Laurent-Charvet et al., 2002, 2003; Wang et al., 2006). Post-collisional pull-apart basins, with bimodal magmatism (e.g. Baiyanggou, SE of Urumqi) occurred during the events. The structures related to the Paleozoic were reactivated by multiple intracontinental tectonic events which resulted in repeated uplift, erosion, folding and thrusting of the Tian Shan Belt over the Junggar basin (Avouac et al., 1993; Charreau et al., 2005). In north Tian Shan, the age of folding is mainly Tertiary (Avouac et al., 1993; Charreau et al., 2005), although several Mesozoic tectonic events are recognized (Hendrix et al., 1992).

The term "South Junggar" used in this paper refers to the geographic location of the samples and it is not related to a peculiar geologic unit. The Permian terrigenous rocks that we sampled can be considered either as the sedimentary cover of the Carboniferous Bogda Shan arc because of a weak unconformity between Carboniferous and Permian layers or as the lowest strata of the Junggar Basin since the sedimentary sequence is continuous from Permian to present.

\subsection{West Junggar Mountains}

The West Junggar Mountains are located at the northwestern edge of the Junggar basin and extends to the Kazakh frontier (Fig. 1). To the south, West Junggar is limited by the active Alashankou Fault, a reactivation of the Permian Chingiz-Alakol-North Tian Shan Shear Zone. To the north, West Junggar is separated from the Chinese Altai by the $50 \mathrm{~km}$ wide sinistral Late Carboniferous-Permian Irtysh-Gornotsaev Shear Zone (Laurent-Charvet et al., 2003; Buslov et al., 2004). The northern part of West Junggar, in Sawuer and Shaburt Mountains along the Kazakh border, consists of Devonian to Carboniferous volcanic-arc rocks, which unconformably overlie an Early Paleozoic accretionary complex (Fig. 3; Feng et al., 1989; Chen et al., 2009). The southern part of West Junggar Mountains consists of an association of Ordovician to Carboniferous ophiolitic mélanges and turbidite sequences (Feng et al., 1989; Zhang et al., 1993). Although these 
accreted terranes are affected by post-collisonal tectonics, their architecture suggests a northdipping subduction (Buckman and Aitchinson, 2004). This subduction zone might extent to the west into Kazakhstan. Its strike becomes progressively rotated by $180^{\circ}$ in Central Kazakhstan and thus connects to the North Tian Shan subduction zone (Fig. 1). This horseshoe shape corresponds to the Devonian to Carboniferous Kazakh orocline (Sengör and Natal'in, 1996; Abrajevitch et al., 2007). Post-collisional magmatic rocks cross-cut the accretionary complex (Chen and Jahn, 2004; Han et al., 2006; Geng et al., 2009), and Permian continental deposits unconformably overlie Carboniferous turbidites. Ductile to brittle deformation occurs along SW-NE trending sinistral faults, like Darbut Fault. Since the Paleozoic, intracontinental basins, like Junggar were filled by Mesozoic and Cenozoic sedimentary rocks covering the Paleozoic basement. Active top-to-the SE thrusting allows the Paleozoic basement of the West Junggar Mountains to be locally exposed along the Darbut Fault or the Uhre thrust near Karamay City.

\subsection{Paleomagnetic sampling}

In South Junggar, three Permian formations were sampled namely the Early Permian Tashikula formation $\left(\mathrm{P}_{1 \mathrm{t}}\right)$; and Late Permian rocks of Wulapo and Jingjingzhigou formation $\left(\mathrm{P}_{2 \mathrm{j}}\right.$ and $\left.\mathrm{P}_{2 \mathrm{n} n}\right)$, outcropping in Jingjingzi Valley and Shiren Valley, East of Urumqi (Fig. 2). The Tashikula formation $\left(\mathrm{P}_{1 \mathrm{t}}\right)$ consists of fine to medium-grained greywacke, which contain lithic fragments of volcanic-arc rocks, alternating with mudstone. The age of this formation is defined by Pugilis $s p$., Septimyalina sp., Mesoconularia sp., Neoggerathiopsis sp. (XBGMR, 1965; Carroll et al., 1995; Wartes et al., 2002). 4 sites have been sampled in this formation (Table 1). The Late Permian species Labiisporites, Illinites, Darwinula Darwinuloides, and Tomiella, have been found in the Wulapo and Jingjingzigou formations (XBGMR, 1965; Zhang, 1981; Carroll et al., 1995; Wartes et al., 2002). Four and two sites of siltstone and sandstone have been drilled in these two formations (Table 1), respectively. Permian rocks rest with a slight unconformity upon Late Carboniferous 
volcanic-arc rocks of Bogda Shan, and are in turn overlain by Triassic detrital series (Wartes et al., 2002). This area is marked by fold and thrusts related to the Cenozoic intracontinental orogeny (Molnar and Tapponnier, 1975)

In West Junggar, the ages of the sedimentary rocks from Xibeikulasi and Tailegula formations are less well constrained, since fossils are rare; however, a few fossil discoveries allow an Early Carboniferous age to be established (XBGRM, 1966). Fourteen sites were sampled in greywacke of Xibeikulasi and Tailegula formations in the south-west of Karamay City, along the road S221, between Miaoergou and Tacakuo (Fig. 3, Table 1). These rocks are folded, with a slaty cleavage developed in fine-grained facies. Deformation is postdated by abundant Late Paleozoic plutons (Chen and Jahn, 2004; Han et al., 2006; Geng et al., 2009) and all the sites are located within thermal aureoles. In addition, some sampling sites are located near Permian mafic dykes that belong to a large dyke swarm (XBGRM, 1966; Li et al., 2004; Qi, 1993). In all these sites, prominently silicified hornfels bear evidence of a strong thermal overprint. The timing of these late-orogenic processes will be furthermore discussed in detail.

Eight to ten cores were drilled from each site with a portable gasoline drill. Cores were orientated by both magnetic and solar compasses, when it was possible. The average difference between these two azimuths is about $2.9^{\circ} \pm 2^{\circ}$ and $4.3^{\circ} \pm 3^{\circ}$ for Urumqi and Karamay areas, respectively. These values were used to correct the orientation of samples measured by magnetic compass alone and the sedimentary bedding measurements.

\section{Paleomagnetic study}

\subsection{Laboratory processing}

Before the measurements of the magnetic remanence of this paleomagnetic collection, its magnetic mineralogy was investigated by several methods in the Laboratory of Rock Magnetism of 
Institut des Sciences de la Terre d'Orléans (ISTO). Thermal magnetic (Curie point) experiment and the measurements of Anisotropy of Magnetic Susceptibility were carried out by Agico $®$ CS3 coupled KLY-3s kappabridge, the measurements of Isothermal Remanent Magnetization (IRM, acquired with ASC Scientific IM-10-30), Lowrie test (Lowrie, 1990) and magnetic remanence were performed with Agico ${ }^{\circledR}$ JR5A spinner magnetometer. The thermal and Alternative Field (AF) demagnetization are realized by lab-built furnace and Agico ${ }^{\circledR}$ LDA-3 demagnetizer, respectively.

Six to eight specimens were selected from each site to be demagnetized by about 16 steps with both thermal (up to $690 \mathrm{C}^{\circ}$ ) and AF (up to $100 \mathrm{mT}$ ) methods. Progressive demagnetizations were plotted on orthogonal vector diagrams (Zijderveld, 1967) and magnetic remanent directions were isolated by the principal component analysis (Kirschvink, 1980). Site-mean directions were computed by spherical statistic (Fisher, 1953). Paleomagnetic softwares written by Cogné (2003) and Enkin (unpublished) were used for the data analysis.

\subsection{Magnetic mineralogy}

Figure 4 presents the results of the magnetic mineralogical investigations on the representative samples from both south (left column) and west of Junggar basin (right column).

Concerning the samples from South Junggar, the fine to medium-grained greywacke of Tashikula formation $\left(\mathrm{P}_{1 \mathrm{t}}\right)$ and siltstone and sandstone of Wulapo and Jingjingzigou formations $\left(\mathrm{P}_{2 \mathrm{w}}\right.$ and $\mathrm{P}_{2 \mathrm{j}}$ ) show similar magnetic behaviors: a saturation of $>95 \%$ below $300 \mathrm{mT}$ (Fig. $4 \mathrm{a}$ ), total demagnetization of the three components of the Lowrie Test (Fig. 4b), and sharp drops of the magnetic susceptibility at $580^{\circ} \mathrm{C}$ (Fig. 4c), suggesting the presence of various-sized titanium-poor magnetite as the principal magnetic remanent carrier.

For the greywacke of Xibeikulasi $\left(\mathrm{C}_{1 \mathrm{x}}\right)$ and Tailegula $\left(\mathrm{C}_{1 \mathrm{t}}\right)$ formations from West Junggar, IRM measurements (Fig. 4d) indicate that the specimens are saturated more than $80 \%$ at $200 \mathrm{mT}$ and not completely saturated until $1200 \mathrm{mT}$, and Lowrie Test curves (Fig. 4e) present two drops of 
magnetic remanence at about $300-350^{\circ} \mathrm{C}$ and $580^{\circ} \mathrm{C}$, corresponding to maghemite (titanomaghemite) and magnetite. These observations are confirmed by thermal magnetic (Curie) measurements (Fig. 4f) with magnetic susceptibility dropping at around $300-350^{\circ} \mathrm{C}$ and $580^{\circ} \mathrm{C}$.

To summarize the investigation of remanent carriers, the soft coercive minerals, such as magnetite, with probably a few maghemite, are the principal remanent carriers with small percentage of high coercive minerals for all collection.

\subsection{Paleomagnetic directional data}

The progressive demagnetization show two magnetic components for most of the measured samples differentiated at about $300^{\circ} \mathrm{C}$ (Figs. 5a and 5b, 6a and 6b). The low temperature component (LTC, up to $200-300^{\circ} \mathrm{C}$ ) isolated from the 10 Permian sites from South Junggar present a wellgrouped mean direction with a negative fold test (McElhinny, 1964): $\mathrm{Dg}=5.4^{\circ}, \mathrm{Ig}=60.1^{\circ}, \mathrm{kg}=$ $46.5, \alpha_{95}=7.2^{\circ}$ and Ds $=328.0^{\circ}$, Is $=15.4^{\circ}, \mathrm{ks}=12.9, \alpha_{95}=14^{\circ}$ with $\mathrm{n}=10$ (labels $\mathrm{g}$ and $\mathrm{s}$ correspond to the geographic and stratigraphic coordinate system respectively). This mean direction in geographic coordinates is close to the Present Earth Field (PEF, D $=1.4^{\circ}, \mathrm{I}=62.9^{\circ}$ ). The LTC from West Junggar show a dispersed distribution. Therefore, no mean direction has been calculated. As this LTC does not offer any information on further geodynamic implication, we will only discuss the high temperature component (HTC) below.

Before presenting the statistical results of each formation from both areas, some common characteristics of HTC may be described as following. Unblocking temperature of this component is in the $300^{\circ} \mathrm{C}$ and $350^{\circ} \mathrm{C}$ interval. The thermal demagnetization of this remanence shows a linear decay of the magnetization to the origin and a total demagnetization before $585^{\circ} \mathrm{C}$ (see demagnetization curves in Figs. 5 and 6). The above observations confirm again that (various-sized titanium-poor) magnetite is the principal remanence carrier. Conversely to LTC, this component only presents a reverse polarity for the characteristic magnetic direction. 


\subsubsection{Paleomagnetic data from South Junggar}

\subsubsection{Tashikula Formation $\left(P_{1 t}\right)$}

Fisher spherical statistics (Fisher, 1953) on the 4 sites (30 cores) of fine to medium-grained greywacke show a well grouped direction of each site with $\alpha_{95}<8^{\circ}$ (Table 1). Site mean directions and the corresponding statistical parameters are presented in Table 1 and Figures $5 \mathrm{c}$ and $5 \mathrm{~d}$. A $\mathrm{P}_{1}$ age-mean direction has been further calculated for this locality: $\mathrm{Dg}=254.8^{\circ}, \mathrm{Ig}=-58.4^{\circ}, \mathrm{kg}=$ 255.2, $\alpha_{95}=5.8^{\circ}$ for the geographic coordinates and Ds $=167.4^{\circ}, \mathrm{Is}=-67^{\circ}, \mathrm{ks}=417.5, \alpha_{95}=4.5^{\circ}$ with $\mathrm{n}=4$ sites for the stratigraphic coordinates (Table 1).

\subsubsection{Wulapo and Jingjingzigou formations $\left(P_{2 w}\right.$ and $\left.P_{2 j}\right)$}

Four and two sites of siltstone and sandstone, from Late Permian Wulapo formation and Jingjingzhigou formation, respectively, show similar magnetic behaviors as Lower Permian samples. $\mathrm{A} \mathrm{P}_{2}$ age-mean direction has been therefore calculated: $\mathrm{Dg}=286.0^{\circ}, \mathrm{Ig}=-44.6^{\circ}, \mathrm{kg}=$ $18.6, \alpha_{95}=16^{\circ}$ for the geographic coordinates and Ds $=140.1^{\circ}, \mathrm{Is}=-59.3^{\circ}, \mathrm{ks}=253.9, \alpha_{95}=4.2^{\circ}$ with $\mathrm{n}=6$ sites for the stratigraphic coordinates (Table 1, Figs. 5e and 5f).

Because of weak bedding variation for only 4 sites, the fold test for Lower Permian Tashikula formation is not conclusive though the statistical parameter $(\mathrm{k})$ is improved after bedding correction. However, the regional fold test for Tashikula, Wulapo and Jingjingzhigou formations is positive at 95\% level (McElhinny, 1964).

\subsubsection{West Junggar Mountains}

Fourteen sites of greywacke sampled in the Early Carboniferous Xibeikulasi and Tailegula formations in the southwest of Karamay City (Fig. 3) show significantly different magnetic behaviors from above though the majority of sites show still coherent directions within the site. 
These same age rocks reveal two distinct groups of directions in geographic coordinates and highly dispersed directions in the stratigraphic directions (Fig. 6; Table 1). Statistically, the dispersion of site-mean directions does not yield one single Fisherian age mean direction for this locality. Two mean directions have been therefore computed for this area (Table 1). The first group consists of 9 sites: $\mathrm{Dg}=153.5^{\circ}, \mathrm{Ig}=-51.0^{\circ}, \mathrm{kg}=81.6, \alpha_{95}=5.7^{\circ}$ and $\mathrm{Ds}=164.4^{\circ}, \mathrm{Is}=-48.4^{\circ}, \mathrm{kg}=2.2, \alpha_{95}=$ $45.8^{\circ}$ (Figs. $6 \mathrm{c}$ and $6 \mathrm{~d}$ ), and the second consists of 5 sites: $\mathrm{Dg}=212.7^{\circ}, \mathrm{Ig}=-57.9^{\circ}, \mathrm{kg}=196.9, \alpha_{95}$ $=5.5^{\circ}$ and $\mathrm{Ds}=229.8^{\circ}, \mathrm{Is}=18.4^{\circ}, \mathrm{ks}=217.8, \alpha_{95}=5.2^{\circ}$ (Figs. 6e and 6f). The fold test is negative (McElhinny, 1964). The geological significance of the direction grouping will be analyzed in the Discussion section.

\section{Discussion}

Progressive demagnetizations have successfully isolated two magnetic components. The low temperature component (LTC), called also the viscous magnetization, presents only a normal magnetic polarity and directions close to the PEF, therefore, records the recent geomagnetic field. The high temperature components (HTC), principally carried by magnetite with probably little maghemite, reveal a solo reversed polarity. The directions are generally consistent within site with $\alpha_{95}<10^{\circ}$. Before interpreting tectonically these new paleomagnetic data, some discussion on their reliability and age of magnetization is deserved, as it is well known that Central Asia experienced a multiphase tectonic evolution.

4.1. Reliability and age of the magnetic remanence

Although no direct evidence of a penetrative deformation (except tilting and folding of the strata) can be observed in the field, the measurement of Anisotropy of Magnetic Susceptibility (AMS) has been carried out on the paleomagnetic collection in order to assess the effect of rock deformation. A weak anisotropy has been observed with the anisotropy degree $\mathrm{P}^{\prime}<1.05$ (Fig. 7a) 
suggesting that these rocks have not experienced intensive deformation since their formation. The statistical results of the three principal magnetic anisotropic axes show a well-grouped vertical $\mathrm{K}_{3}$ $\left(\mathrm{D}=60.7^{\circ}, \mathrm{I}=81.8^{\circ}\right.$, pole of magnetic foliation; Fig. $\left.7 \mathrm{~b}\right)$ after bedding corrections. These observations indicate that the magnetic fabrics developed during the sedimentation. Furthermore, the original deposition surface should be close to horizontal.

Only a reversed polarity has been isolated from HTCs of all rocks dated between the Early Carboniferous and the Late Permian. These remanent ages are consistent with the Kiaman PermoCarboniferous Reversed Superchron (320 to 260 Ma; Hounslow et al., 2004). The mean direction deduced from the HTC is distinguishably different from PEF, Mesozoic or Cenozoic magnetic directions (Table 1; Chen et al., 1992 and 1993). It is reasonable to assume that the corresponding magnetic remanence was acquired before 260 Ma. However, the Late Paleozoic time is the main period of accretion in the Central Asia Orogenic Belt, including the Paleozoic Tian Shan range. Numerous magmatic events took place in this region, which could affect the magnetic remanence. In order to check if this remanence is primary or secondary, each section should be discussed.

Concerning the sandstone of the South Junggar area, the stratigraphically well-constrained sedimentary rocks present positive fold tests for both Early and Late Permian directions at 95\% statistic level (McElhinny, 1964). With the solo reverse magnetic polarity isolated from these formations, the characteristic tilt-corrected directions can be considered as primary magnetizations. Therefore two paleomagnetic poles have been calculated for Early Permian $\left(\mathrm{P}_{1} ; \lambda=79.5^{\circ} \mathrm{N}\right.$, $\Phi=36.6^{\circ} \mathrm{E}, \mathrm{A}_{95}=6.8^{\circ}$ with $\left.\mathrm{n}=4\right)$ and Late Permian periods $\left(\mathrm{P}_{2} ; \lambda=60.4^{\circ} \mathrm{N}, \Phi=4.7^{\circ} \mathrm{E}, \mathrm{A}_{95}=5.4^{\circ}\right.$ with $\mathrm{n}=6$ ), respectively.

In the Western Junggar Mountains, the ages of the remanence for the sites of Early Carboniferous Xibeikulasi and Tailegula Formations are however less constrained. Recent U/Pb datings of zircon from altered tuffs from Baogutu Formation yield a Visean age (between 343 and $328 \mathrm{Ma}$; Wang and Zhu, 2007; An and Zhu, 2009) and Late Carboniferous detrital zircons were 
found in similar formation near Karamay (Zhang, 2009). Moreover, if these rocks were representative of Early Carboniferous period, both normal and reverse polarities should be identified, as the reversal frequency is relatively high at that time (Hounslow et al., 2004). The negative fold test with a decrease of the precision parameter after bedding corrections reveals a remagnetization of these Carboniferous rocks (Table 1). The observation of solely reverse polarities for this long Carboniferous sedimentary series may indicate that the age of the remanence is probably not older than the lower limit of the Kiaman superchron (i.e. 325 Ma; Hounslow et al., 2004). This magnetization is probably related to magmatic events and low-grade metamorphism. Hornfelses (Fig. 8a) and low-grade metamorphic minerals, such as prehnite and pumpelleyite (Fig. 8b) can be observed in greywackes. As described in the previous section, two well grouped mean directions have been revealed in this area (Table 1). The sampling sites of these two groups are located very close to the pluton boundary and mafic dykes, respectively. The first group of nine sites is located near the Miaoergou pluton and the remaining five sites are in the vicinity of mafic dykes (Fig. 3). The Miaoergou, Akebastaw or Karamay plutons (Fig. 3) were emplaced between 320 and $300 \mathrm{Ma}$ (Chen and Jahn, 2004; Han et al., 2006; Geng et al., 2009). Several generations of intrusive rocks characterize the dyke swarm, with high-Mg microdiorites at ca. $320 \mathrm{Ma}$ (Yin et al., 2010) and dolerites or diabases at $260 \mathrm{Ma}$ (Li et al., 2004; Qi, 1993). A compilation of recent dating results exhibits two magmatic peaks at $300 \mathrm{Ma}$ and $260 \mathrm{Ma}$ (Fig. 8c). We thus suggest that these two thermal events may be the cause of the observed remagnetizations and, therefore, the ages of the two groups of remagnetization may correspond to those of granitic pluton and mafic dyke swarm, i.e. Late Carboniferous-Early Permian (320-300 Ma) and Late Permian (about $260 \mathrm{Ma}$ ), respectively. Two paleomagnetic poles have been calculated from the in situ directions of this collection for West Junggar at $\lambda=65.3^{\circ} \mathrm{N}, \Phi=329.7^{\circ} \mathrm{E}, \mathrm{A}_{95}=6.3^{\circ}$ with $\mathrm{n}=9$ for the Late Carboniferous-Early Permian and at $\lambda=64.8^{\circ} \mathrm{N}, \Phi=179.5^{\circ} \mathrm{E}, \mathrm{A}_{95}=6.9^{\circ}$ with $\mathrm{n}=5$ for the Late Permian (Table 2). Since no obvious declination deviation has been observed among the sites across 
the Darbut Fault (Fig. 3), it seems that no major internal deformation associated with this shear zone likely occurred within the West Junggar block since the Late Carboniferous-Early Permian.

\subsection{Comparison with previous paleomagnetic results}

Eight paleomagnetic poles, including two from this study, are available for South Junggar (Tab. 2). Among them, two poles are distinguished by abnormal declination and/or inclination with respect to others (Poles 1 and 2 in Table 2). Pole 1 displayed a deviating declination probably due to local rotation along strike slip faults. Pole 2 from volcanic lava flows (Late Carboniferous Liushugou Formation, Li et al., 1991) may represent a short time record of the magnetic field due to rapid cooling. Moreover, the initial geometry of these flows is also questionable for the bedding corrections, and these poles were used for tectonic implications. Though the ages, constrained by paleontological evidence are bracketed between $\mathrm{C} 3$ and $\mathrm{P} 2$, the remaining poles show a relatively good consistency of the paleolatitude with a slight declination variation (Fig. 9a). Within the uncertainty, the pole from Tianchi volcanic rocks seems having experienced a weak clockwise rotation with respect to others (Pole 8 in Table 2; Nie et al., 1993). It may be due to the secular variation influence on the data. According to the statistical consistency among these poles, a Late Carboniferous-Late Permian paleomagnetic pole has been calculated at $\lambda=77.0^{\circ} \mathrm{N}, \Phi=7.6^{\circ} \mathrm{E}$, $\mathrm{A}_{95}=9.9^{\circ}$ with $\mathrm{n}=6$ (Fig. $\left.9 \mathrm{a}\right)$.

Concerning West Junggar, poles 11 and 12 in Table 2 of Devonian to Carboniferous rocks from Shaburt Mountains with Late Carboniferous-Early Permian remanent age show a good statistical consistency with that of our study (Fig. 9b). Nevertheless the Late Carboniferous-Early Permian pole from Zhao et al. (1990; Pole 9 in Table 2) obtained from a granite without control neither on its initial setting position nor on the recording time of the magnetic field during its emplacement shows a significant difference with others. A Late Carboniferous to Early Permian pole has been calculated for West Junggar, from poles $10-12$ only at $\lambda=68.2^{\circ}, \Phi=326.7^{\circ}, \mathrm{A}_{95}=12.6^{\circ}$ with $\mathrm{n}=3$ 
(Fig. 9b). For the Late Permian data, the Permian pole from Li et al. (1989; Pole 13 in Table 2) obtained from mafic dykes strongly deviates from the others poles probably due to uncertainty on the initial inclination and/or rapid cooling. The Late Permian poles from Upper Permian detrital rocks and from overprinted basalts (poles 14 and 15, Zhao et al., 1990) are similar to the five dykerelated sites-mean direction of Karamay section with an insignificant angular difference of $19.1^{\circ} \pm$ $27.5^{\circ}$ (Fig. $9 b$ ). A Late Permian pole has also been calculated at $\lambda=53.0^{\circ} \mathrm{N}, \Phi=183.9^{\circ} \mathrm{E}, \mathrm{A}_{95}=16.6^{\circ}$ with $n=3$ for West Junggar (Fig. 9b).

\subsection{Relative motions between blocks}

As described in the Introduction section, in the paleogeographic reconstruction of Wang et al. (2007), the paleomagnetic data from West Junggar were used to represent the entire Junggar Block considering that the latter is a rigid body during the Late Carboniferous. The new results from both South and West Junggar of this study allow us to enhance the understanding of the Late Paleozoic paleogeographic evolution of Central Asia. Table 2 shows the poles used to discuss the relative motions between South Junggar, West Junggar, NE Kazakhstan, Tarim, Yili and Siberia.

Recent studies in North Kazakhstan and especially in the Chingiz Range yield eight poles for the Late Carboniferous-Early Permian and the Late Permian (Collins et al., 2003; Levashova et al., 2003a; 2003b; 2009; Abrajevitch et al., 2008; Table 2; Fig. 9c). Pole $17\left(\lambda=13.3^{\circ} \mathrm{N}, \Phi=138.3^{\circ} \mathrm{E}\right.$, $\mathrm{A}_{95}=6.9^{\circ}$ ) from Abrajevitch et al. (2008) was used as the Late Carboniferous North Kazakhstan pole. Five Late Permian paleomagnetic poles are well grouped and a mean pole was calculated at $\lambda=46.6^{\circ} \mathrm{N}, \Phi=171.6^{\circ} \mathrm{E}, \mathrm{A}_{95}=8.4^{\circ}$ with $\mathrm{n}=5$ for Late Permian (Fig. 9c). The two remaining Late Carboniferous to Early Permian and Late Permian poles are scattered with others probably due to local motion produced by the Chingiz Fault (Pole 19 in Levashova et al., 2003b) or oversteep inclination (Pole 21 in Levashova et al., 2003a; Table 2). The paleomagnetic poles of Siberia, Yili and Tarim blocs are discussed in Wang et al., (2007). 
Figures 9d and 9e present the relative motions among the West Junggar, South Junggar, NE Kazakhstan, Tarim, Yili and Siberia at the Late Carboniferous-Early Permian and the Late Permian. Several remarkable features may be outlined, namely: (1) South Junggar remains in a relatively stationary position during this period; (2) South Junggar was at a higher paleolatitude than West Junggar at C3-P1 time, although respective paleolatitudes of $33.1^{\circ}+/-12.6^{\circ}$ and $44.6^{\circ}+/-9.9^{\circ}$ are not statistically different due to rather large confidence errors; (3) West Junggar underwent an important motion during C3-P1 and P2 with respect to NE Kazakhstan and Siberia, essentially by relative rotations as they are aligned on the small circle centered at the sampling region. (4) These three latter areas form a relatively rigid block since P2, however, Tarim, Yili and South Junggar still experienced relative motions after P2.

From above relative motions, quantitative displacements may be calculated. First, the angular difference can describe the consistency or not between two blocks. Secondly, the relative paleolatitude changes and rotations between two concerned blocks can be inferred. These results are synthesized in Table 3 with the geographic reference at $45^{\circ} \mathrm{N}$ and $84^{\circ} \mathrm{E}$.

For the C3-P1 period, the angular difference between South and West Junggar is about $14.6^{\circ} \pm 16.0^{\circ}$, with a significant paleolatitude discrepancy $\left(14.2^{\circ} \pm 10.0^{\circ}\right.$ for relative latitudinal displacement and $-4.4^{\circ} \pm 16.2^{\circ}$ for relative rotation). The angular differences become larger and attend to $69.5^{\circ} \pm 13.0^{\circ}$ and $98.3^{\circ} \pm 14.4^{\circ}$ of West Junggar to Siberia and Kazakhstan, respectively, which are essentially due to relative rotations, i.e. $-84.4^{\circ} \pm 12.0^{\circ}$ and $-130.1^{\circ} \pm 13.3^{\circ}$, respectively (Fig. 9d).

During Late Permian, the angular difference among paleomagnetic poles from West Junggar, NE Kazakhstan and Siberia becomes not significant $\left(10.2^{\circ} \pm 18.6^{\circ}, 15.0^{\circ} \pm 18.0^{\circ}\right.$, respectively). However, the angular differences are still relatively important, principally due to relative rotations, between West Junggar-NE Kazakhstan-Siberia and South Junggar, Yili and Tarim, $61.7^{\circ} \pm 18.7^{\circ}$, 
$28.5^{\circ} \pm 19.4^{\circ}$ and $13.9^{\circ} \pm 15.7^{\circ}$, respectively (Table 3 and Fig. 9e). The difference in latitude is less significant, i.e. $17.2^{\circ} \pm 12.1^{\circ}, 15.1^{\circ} \pm 12.6^{\circ}$ and $7.5^{\circ} \pm 10.8^{\circ}$ respectively.

\subsection{Tectonic implications}

The first important implication from this new paleomagnetic study is the existence of significant relative movements between West and South Junggar. In other words, the Junggar basin cannot be considered as a rigid body at least until the Mesozoic since the P2 poles are still significantly different. Moreover, West Junggar is paleogeographically closer to Kazakhstan and Siberia than to South Junggar, as the P2 poles of West Junggar, Siberia and Kazakhstan are consistent (Fig. 9e). This implies that West Junggar, NE Kazakhstan and Siberia seem having been agglomerated since P2. As described previously, significant post Late Permian rotations between this agglomerated block and South Junggar, Tarim and Yili can be inferred from their respective poles. These rotations reveal a continuity of rotational movements at least until Early Mesozoic between and West-Junggar-Kazakhstan-Siberia.

As mentioned above, the angular differences between the paleomagnetic poles of the aforementioned blocks are mainly due to relative rotations along major faults during the Late Carboniferous to Late Permian period. Latitudinal displacement also occurs between West Junggar and South Junggar during the C2-P1. The Early Permian clockwise rotation of North Kazakhstan with respect to Siberia has been interpreted to result from oroclinal bending with individualization of three different limbs (Levashova et al., 2003a, 2009; Van der Voo et al., 2006; Abrajevitch et al., 2007, 2008). Nevertheless, West Junggar underwent a counterclockwise rotation with respect to Siberia and the origin of this motion may be discussed as follows. West Junggar represents the easternmost end of the Kazakhstan orocline and is limited to the northeast by the Gornotsaiev and Irtysh faults. These tectonic structures represent the reactivated suture zone of the Devonian to Carboniferous Ob-Zaisan Ocean (Fig. 1b; Filippova et al., 2001; Windley et al., 2007), the 
boundary between Kazakhstan and Siberia, that collided during Late Carboniferous. Geological and geochemical evidences also testify a contemporaneous collision of the Kazakh Orocline with Junggar block. These collisions can be considered as diachronous or "oblique" as only West Junggar is involved. Hence the West Junggar ribbon is sandwiched within Junggar microcontinents, Siberian margin and the Kazakh orocline. This oblique collision may lead to the counterclockwise rotation of West Junggar with respect to Siberia with a complex buckling of an oroclinal ribbon (Fig $1 \mathrm{~b}$ and $\mathrm{c}$ ). The regional structure with NE-SW and NW-SE trends of the Late Devonian accretionary front in West Junggar and North Kazakhstan, respectively (Fig. 1b), is a consequence of the relative rotation between those two blocks. In this model, Early Permian left lateral motions along Gornotsaiev and Irtysh faults (Meltnikov et al., 1998; Laurent-Charvet et al., 2003; Buslov et al., 2004) could accommodate that rotation. We also propose that the development of this bent back structure might initiate strike slip faulting along the Chingiz-Alakol-North Tian Shan Shear zone and relative dismembering of the orocline.

To the south, in Tian Shan, the right-lateral shearing has produced the relative rotation of Yili block with respect to Tarim along the Nikolaiev-Nalati Tectonic Line, and with respect to South Junggar along the Chingiz-Alakol-North Tian Shan Fault (Yin and Nie, 1996; Laurent-Charvet et al., 2003, Wang et al., 2007). Further to the west, Permian rotations accommodated by strike-slip faults were also decribed (Van der Voo et al., 2006). Strike slip faulting along the Central Kazakhstan Fault (Samugyn, 1974) has been observed, but until now no relative rotations are reported.

Since the Late Permian, as their poles are statistically coherent, West Junggar, Siberia and North Kazakhstan formed an amalgamated block (Fig. 9e). The relative motions of Tarim, Yili and South Junggar with respect to this welded block are characterized by a northward increase of the amount of anticlockwise rotations, i.e. $-13.9^{\circ} \pm 15.7^{\circ},-28.5^{\circ} \pm 19.4^{\circ}$ and $-61.7^{\circ} \pm 18.7^{\circ}$, respectively (Table 
3). Late Permian-Early Triassic right lateral faults in both North and South Tian Shan may have accommodated such rotations; and left-lateral fault in Altai as well (Figs. 1b and 10).

Considering these Late Permian relative rotations, it is possible to make quantitative estimates of the displacement along these faults since Late Permian. According to the geometry of major structures that separate the mentioned blocks, we can define the Euler pole to quantify the relative motion along the structure (Table 4, Fig. 10). The Nalati fault in Chinese Tianshan, also called the Nikolaiev Tectonic Line (Burtman, 1975) in Kirghizstan, is the major fault that separates Tarim and Yili (Zhao et al., 2003; Wang et al., 2007). Though sinistral motions have been described in Kirghizstan (Mikolaichuk et al., 1995), the timing of deformation is badly constrained. More to the East, a dextral kinematics of the fault has been better described and the deformation is dated between $265 \mathrm{Ma}$ and $250 \mathrm{Ma}$ (Ar-Ar dating; de Jong et al., 2009; Wang et al., 2010). Its well preserved linear shape allows to estimate an Euler pole position at ca. $54^{\circ} \mathrm{N}, 76^{\circ} \mathrm{E}$, with a radius of about $1690 \mathrm{~km}$. Therefore the $14.0^{\circ} \pm 12.9^{\circ}$ counterclockwise rotation of Yili with respect to Tarim corresponds to its eastward displacement of $410 \mathrm{~km} \pm 380 \mathrm{~km}$ (Table 4).

The boundary between Yili and South Junggar is characterized by a dextral long-lived shear zone called the Chingiz-Alakol-North Tian Shan Shear zone, merging in the Main Tian Shan Shear zone to the east (Zhou et al., 2001; Zhao et al., 2003; Wang et al., 2006, 2007). Dextral criteria can be observed along these faults (Laurent-Charvet et al., 2002; 2003; Wang et al., 2006, 2007) and Ar-Ar dating yield ages ranging from $290 \mathrm{Ma}$ to $240 \mathrm{Ma}$ for the deformation (Yin and Nie, 1996; Zhou et al., 2001; Laurent-Charvet et al., 2002, 2003). The center of the best fitting small circle intercepting this curved shear zone is around $50^{\circ} \mathrm{N}, 92^{\circ} \mathrm{E}$, with a radius of about $880 \mathrm{~km}$. The estimate of the post Late Permian displacement along the Chingiz-Alakol-North Tian Shan Shear zone is thus $490 \mathrm{~km} \pm 250 \mathrm{~km}$, corresponding to the $-32.4^{\circ} \pm 16.4^{\circ}$ counterclockwise rotation of South Junggar with respect to Yili (Table 4). 
As presented in above sections, the Irtysh-Gornotsaev Shear Zone is a major tectonic zone in the Altaids and it is characterized by a sinistral sense of shear and ages of deformation bracketed between 290 Ma to 240 Ma (Ar-Ar dating; Meltnikov et al., 1997; 1998; Vladmirov et al., 1998; Trivin et al. 2001; Laurent-Charvet et al., 2003; Buslov et al., 2004), with a probable Mesozoic brittle reactivation (Allen et al., 1995). The bent shape of the shear zone proposes an Euler pole at $56^{\circ} \mathrm{N}, 101^{\circ} \mathrm{E}$, with a radius of about $1220 \mathrm{~km}$. The estimated displacement for the post Permian displacement is about $1570 \mathrm{~km} \pm 280 \mathrm{~km}$, associated with a $-73.9^{\circ} \pm 13.1^{\circ}$ couterclockwise rotation of South Junggar with respect to Siberia (Table 4). This value is slightly higher than that predicted by a previous study $(870 \mathrm{~km} \pm 370 \mathrm{~km}$, Wang et al., 2007). Sum of post Late Permian and Early Permian displacement of $140 \mathrm{~km} \pm 250 \mathrm{~km}$ (associated with $6.4^{\circ} \pm 11.7^{\circ}$ couterclockwise rotation of South Junggar with respect to Siberia, Table 4) along the Irtysh-Gornotsaev Shear Zone give a total value of $\approx 1700 \mathrm{~km}$, comparable with the value of $2000 \mathrm{~km}$ predicted by Sengör and Natal'in, (1996). The new estimate of the Late Carboniferous to Early Permian displacement along the Irtysch Fault is significantly different from that of $620 \mathrm{~km} \pm 320 \mathrm{~km}$ predicted by Wang et al., (2007), because Junggar was considered as a rigid block and an averaged pole from West and South Jungar was used to calculate the displacement along this fault in Wang et al. (2007). The consistence of the Cretaceous poles of Mongolia, South Junggar and Siberia (Chen et al., 1993; Hankard et al., 2005) suggests that the bulk of relative motion mentioned above was completed before Cretaceous and possibly Middle Triassic time (Lyons et al., 2002), although Jurassic motions are also described (Allen et al., 1995). Further studies on Triassic rocks around the Junggar Basin will probably provide better age constraints on these events. It is worth to note that above mentioned quantitative displacements should be considered with caution as they depend on the quality of paleomagnetic data and the structure geometry which is used to define the position of Euler poles. Paleomagnetic studies in this area are scarce and the available data probably 
insufficient with respect to the extreme complexity of this region which has suffered multiple tectonic events since the Paleozoic.

\subsection{Tentative reconstruction}

Combined with previous paleomagnetic data, these new results make possible to construct hypothetical scenarios of the geodynamical evolution of this western part of Central Asia during Late Paleozoic times. Four stages can be distinguished as follows (see also Fig. 11):

4.5.1. Carboniferous (before 320 Ma; Fig. 11a)

Two subduction zones were active. In the north, the Ob-Zaisan Ocean was subducting under the North Kazakhstan and the Siberia (Early Paleozoic Altai accretionary complexes) as active margins (Filippova et al., 2001; Briggs et al., 2007). The Junggar Ocean was enclosed in the Kazakhstan orocline extending from Tian Shan to Kazakhstan (Abrajevitch et al., 2008). Arc magmatism associated with subduction was still active in Kazakhstan, Yili, Bogda Shan and West Junggar, while accretionary wedge developed along the margins (Wang et al., 2006). The Kazakhstan oroclinal bending is marked by a clockwise rotation of North Kazakhstan with respect to Siberia (Grishin et al., 1997 ; Levashova et al., 2003a ; Abrajevitch et al., 2008) and forwards to the closure of this oceanic basin.

\subsubsection{Late Carboniferous-Early Permian (between 320 and 280; Fig. 11b)}

At this time, only a remnant part of the Junggar Ocean was still in subduction in the inner part of the orocline (Windley et al., 2007). The closure of the basin was accommodated by internal deformation of the orocline and by the development of strike slip faults with dextral kinematics in Tian Shan (Laurent-Charvet et al., 2002, 2003; Wang et al.; 2007) and Kazakhstan (Samugyn, 1974) and sinistral kinematics in Altai. The closure of the Ob-Zaisan Ocean and consequently oblique collision led to the counterclockwise rotation of West Junggar with respect to Siberia. 


\subsubsection{Late Permian (between 280 and 260; Fig. 11c)}

The end of Paleozoic is characterized by transcurrent tectonics. Since the Permian, sinistral strike-slip along the Irtysh Fault and dextral strike-slip along the Tian Shan shear zones accomodated the counterclockwise rotation of Tarim, Yili and South Junggar with respect to Siberia. Although important shear zones are recognized in North Kazakhstan or West Junggar, no significant rotations within the blocks are recorded by paleomagnetic data except local rotations in Chingiz range (Levashova et al., 2003b).

\subsubsection{Present (Fig. 11d)}

Since Permian or Early Triassic, the Central Asia has experienced successive reactivations due to the agglomeration of Tibetan blocks and the collision India-Eurasia. These compressive tectonics have certainly generated the intracontinental deformation among these blocks and affected the topography of Central Asia (e.g. Molnar and Tapponnier, 1975; Avouac et al., 1993). However, the paleomagnetic studies on Mesozoic (especially Cretaceous) rocks show that the relative motions (rotation and latitudinal displacement) are often statistically insignificant (i.e. the mean difference is less than error bar; Chen et al., 1993), implying that the amount of intracontinental deformation remains weak compared to the Paleozoic period.

\section{Conclusions}

This new paleomagnetic study of Late Paleozoic sedimentary rocks from South and West Junggar yields primary and secondary magnetization, respectively. The magnetic overprints probably result from two well-chronologically constrained magmatic events during Late Carboniferous - Early Permian and Late Permian respectively. These new paleomagnetic results are consistent with the bulk of previously published results from West and South Junggar and clearly 
show a significant paleogeographic discrepancy between them, implying that Junggar was not a rigidly welded block until the end of Paleozoic. Comparison with surrounding blocks, such as North Kazakhstan, Yili, Siberia and Tarim, indicates relatively weak latitudinal motions and important rotations. These rotations are related either to the Kazakh oroclinal bending; or, alternatively to strike-slip faulting. We suggest that in the Late Carboniferous - Early Permian time, West Junggar, located at the easternmost part of the Kazakh orocline and sandwiched between North Kazakhstan and Siberia has been squeezed by approaching close to the latter one and rotated counterclockwise with respect to Siberia. This motion was accommodated by large sinistral and dextral dextral motion in Altai and Tian Shan shear zones, respectively. As evidenced by numerous Ar-Ar dating and kinematic studies (Laurent-Charvet et al., 2002, 2003; Wang et al.; 2007), strike-slip faulting continues in Late Permian, leading to large rotations to achieve the present configuration of Central Asia.

This new model emphasizes the importance of relative rotation among these blocks due to lateral motions along strike-slip faults during the late and post-accretionary orogenic processes However, although no important Cenozoic motion has been recorded, the end of large-scale wrench tectonics is still poorly constrained and more detailed paleomagnetic studies on Early Mesozoic rocks are needed to better clarify the geodynamic history of this region that will complement the understanding of CAOB evolution. 


\section{Acknowledgements}

Many thanks are due to Mrs. Wei Wei and Xu Shaoyong from Peking University for their help in the field work. We also thank Bureau 305 at Urumqi (Xinjiang Uigur Autonous Region) for their important logistical support during fieldwork. This research is a contribution to the project "Paleomagnetic study on the tectonic and paleogeographic evolution of northwest of China" funded by SINOPEC, and co-sponsored by National Nature Science Foundation of China (40821002, 40802043) and National Basic Research Program of China (973 Project Nos. 2009CB825008, 2007CB411301). The first author has benefited a scholarship from French Ministère de l'Enseignement Supérieur et de la Recherche. We express our gratitude to R. Van der Voo and an anonymous referee who considerably improve this article

\section{References}

Abrajevitch, A., Van der Voo, R., Bazhenov, M.L., Levashova, N.M. and McCausland, P.J.A., 2008. The role of the Kazakhstan orocline in the late Paleozoic amalgamation of Eurasia. Tectonophysics 455, 61-76.

Abrajevitch, A., Van der Voo, R., Levashova, N.M. and Bazhenov, M.L., 2007. Paleomagnetic constraints on the paleogeography and oroclinal bending of the Devonian volcanic arc in Kazakhstan. Tectonophysics 441, 67-84.

Allen, M.B., Sengor, A.M.C. and Natalin, B.A., 1995. Junggar, Turfan and Alakol basins as Late Permian to Early Triassic extensional structures in a sinistral shear zone in the Altaid orogenic collage, Central-Asia. Journal of the Geological Society 152, 327-338.

An, F. and Zhu, Y.F., 2009. SHRIMP U-Pb zircon ages of tuff in Baogutu Formation and their geological significances. Acta Petrologica Sinica 25, 1437-1445 (in Chinese). 
Avouac, J.P., Tapponnier, P., Bai, M., You, H. and Wang, G., 1993. Active thrusting and folding along the nothernTien-Shan and Late Cenozoic rotation of the tarim relative to Dzungaria and Kazakhstan. Journal of Geophysical Research-Solid Earth 98, 6755-6804.

Badarch, G., Cunningham, W.D. and Windley, B.F., 2002. A new terrane subdivision for Mongolia: implications for the Phanerozoic crustal growth of Central Asia. Journal of Asian Earth Sciences 21, 87-110.

Bazhenov, Collins, A. Q., Degtyarev, K. E., Levashova, N. M., Mikolaichuk, A. V., Pavlov, V. E., Van der Voo, R., 2003. Paleozoic northward drift of the North Tien Shan (Central Asia) as revealed by Ordovician and Carboniferous paleomagnetism. Tectonophysics 366, 113-141.

Briggs, S.M., Yin, A., Manning, C.E., Chen, Z.L., Wang, X.F., Grove, M., 2007. Late Paleozoic tectonic history of the Ertix Fault in the Chinese Altai and its implications for the development of the Central Asian Orogenic System. Geological Society of America Bulletin $119,944-96$.

Buckman, S. and Aitchison, J.C., 2004. Tectonic evolution of Paleozoic terranes in West Junggar, Xinjiang, NW China. In: Malpas, J., Flectcher, C.J.N., Aitchison, J.C. (Eds.), Aspects of the Tectonic Evolution of China. Geological Society of London Special Publication 226, 101129.

Burtman, V.S., 1975. Structural geology of Variscan Tien Shan, USSR. American Journal of Science A275, 157-186.

Burtman, V.S., 1980. Faults of middle Asia. American Journal of Science 280, 725-744.

Buslov, M.M., Watanabe, T., Fujiwara, Y., Iwata, K., Smirnova, L. V., Safonova, I. Y., Semakov, N. N., Kiryanova, A. P. et al., 2004. Late Paleozoic faults of the Altai region, Central Asia: tectonic pattern and model of formation. Journal of Asian Earth Sciences 23, 655-671. 
Carroll, A.R., Liang, Y. H., Graham, S. A., Xiao, X. C., Hendrix, M. S., Chu, J. C., McKnight, C. L., 1990. Junggar Basin, Northwest China - trapped Late Paleozoic ocean. Tectonophysics $181,1-14$.

Charreau, J., Chen, Y., Gilder, S., Dominguez, S., Avouac, J. P., Sen, S., Sun, D. J., Li, Y. G., Wang, W. M., 2005. Magnetostratigraphy and rock magnetism of the Neogene Kuitun He section (northwest China): implications for Late Cenozoic uplift of the Tianshan mountains. Earth and Planetary Science Letters 230, 177-192.

Charvet, J., Shu, L.S. and Laurent-Charvet, S., 2007. Paleozoic structural and geodynamic evolution of eastern Tianshan (NW China): welding of the Tarim and Junggar plates. Episodes 30, 162-186.

Chen, B. and Arakawa, Y., 2005. Elemental and Nd-Sr isotopic geochemistry of granitoids from the West Junggar foldbelt (NW China), with implications for Phanerozoic continental growth. Geochimica Et Cosmochimica Acta 69, 1307-1320.

Chen, B. and Jahn, B.M., 2004. Genesis of post-collisional granitoids and basement nature of the Junggar Terrane, NW China: Nd-Sr isotope and trace element evidence. Journal of Asian Earth Sciences 23, 691-703.

Chen, J.F., Han, B.F., Ji, J.Q., Zhang, L., Xu, Z., He, G.Q., Wang, T., 2009. Zircon U-Pb ages and tectonic implications of Paleozoic plutons in northern West Junggar, North Xinjiang, China. Lithos In Press, DOI: 10.1016/j.lithos.2009.11.014.

Chen, Y., Cogne, J.P. and Courtillot, V., 1992. New Cretaceous paleomagnetic poles from the Tarim Basin, Northwestern China. Earth and Planetary Science Letters 114, 17-38.

Chen, Y., Courtillot, V., Cogne, J. P., Besse, J., Yang, Z. Y., Enkin, R., 1993. The configuration of Asia prior to the collision of India: Cretaceous paleomagnetic constraints. Journal of Geophysical Research-Solid Earth 98, 21927-21941. 
Coe, R.S., Globerman, B.R., Plumley, P.W. and Thrupp, G.A. 1985. Paleomagnetic results from Alaska and their tectonic implications, in Howell, D.G., ed., Tectonostratigraphic terranes of the Circum-Pacific region, Amer. Assoc. Petrol. Geol., Circum-Pacific Council for Energy and Mineral Resources Series 1, pp. 85-108.

Cogné, J.P., 2003. A MacintoshTM application for treating paleomagnetic data and making plate reconstructions. Geochemical Geophysical Geosystems 4, doi:10.1029/2001GC000227.

Collins, A.Q., Degtyarev, K.E., Levashova, N.M., Bazhenov, M.L. and Van der Voo, R., 2003. Early paleozoic paleomagnetism of east Kazakhstan: implications for paleolatitudinal drift of tectonic elements within the Ural-Mongol belt. Tectonophysics 377, 229-247.

de Jong, K., Wang, B., Faure, M., Shu, L., Cluzel, D., Charvet, J., Ruffet, G., Chen, Y., 2009. New $40 \mathrm{Ar} / 39$ Ar age constraints on the Late Paleozoic tectonic evolution of the western Tianshan (Xinjiang, northwestern China), with emphasis on Permian fluid ingress. International Journal of Earth Sciences 98, 1239-1258.

Degtyarev, K.E. and Ryazantsev, A.V., 2007. Cambrian arc-continent collision in the Paleozoides of Kazakhstan. Geotectonics 41, 63-86.

Demarest, T.J., 1983. Error analysis for the determination of the tectonic rotation from paleomagnetic data, Journal of Geophysical Research 88, 4321-4328

Feng, Y., Coleman, R.G., Tilton, G. and Xiao, X., 1989. Tectonic evolution of the West Junggar region, Xinjiang, China. Tectonics 8, 729-752.

Fisher, R., 1953. Dispersion on a sphere. Proc. R. Soc. London, Ser. A 217, 295-305.

Filippova, I.B., Bush, V.A. and Didenko, A.N., 2001. Middle Paleozoic subduction belts: The leading factor in the formation of the Central Asian fold-and-thrust belt. Russian Journal of Earth Sciences 3, pp. 405-426.

Geng, H.Y., Sun, M., Yuan, C., Xiao, W. J., Xian, W. S., Zhao, G. C., Zhang, L. F., Wong, K., Wu, F. Y., 2009. Geochemical, Sr-Nd and zircon U-Pb-Hf isotopic studies of Late Carboniferous 
magmatism in the West Junggar, Xinjiang: Implications for ridge subduction? Chemical Geology 266, 373-398.

Grishin, D.V., Pechersky, D.M. and Degtyarev, K.E., 1997. Paleomagnetic reconstruction of the Middle Paleozoic structure of Central Kazakhstan. Geotectonics 31, 65-75.

Han, B.F., Ji, J.Q., Song, B., Chen, L.H. and Zhang, L., 2006. Late Paleozoic vertical growth of continental crust around the Junggar Basin, Xinjiang, China (Part I) : Timing of postcollisional plutonism. Acta Petrologica Sinica 22, 1077-1086 (in Chinese).

Hankard, F., Cogne, J.P. and Kravchinsky, V., 2005. A new Late Cretaceous paleomagnetic pole for the west of Amuria block (Khunnen Uul, Mongolia). Earth and Planetary Science Letters 236, 359-373.

Hendrix, M.S., Graham, S.A., Carroll, A.R., Sobel, E.R., McKnight, C.L., Schulein, B.J., and Wang, Z., 1992. Sedimentary record and climatic implications of recurrent deformation in the Tian Shan: Evidence from Mesozoic strata of the north Tarim, south Junggar, and Turpan basins, northwest China: Geological Society of America Bulletin, 104, 53-79.

Hounslow, M.W., Davydov, V.I., Klootwijk, C.T. and Turner, P., 2004. Magnetostratigraphy of the Carboniferous: a review and future prospects. Newsletter on Carboniferous Stratigraphy 22, $35-41$

Hsu, K.J., 1988. Relict back-arc basins: principles of recognition and possible new examples from China. In: Kleinspehn, K.L., Paola, C. (Eds), New Perspectives in Basin Analysis. Springer, pp. 245-263.

Jin, C.W. and Zhang, X.Q., 1993. Geochronology and genesis of the western Junggar granitoids, Xinjiang, China. Scientia Geologica Sinica 28, 28-36 (in Chinese).

Kirschvink, J.L., 1980. The least squares line and the analysis of paleoamgnetic data. Geophys. J. R. Astron. Soc. 62, 699-718 
Kwon, S.T., Tilton, G.R., Coleman, R.G. and Feng, Y., 1989. Isotopic studies veering on the tectonics of the West Junggar region, Xinjiang, China. Tectonics 8, 719-727.

Laurent-Charvet, S., Charvet, J., Shu, L., Ma, R. and Lu, H., 2002. Paleozoic late collisional strikeslip deformations in Tianshan and Altay, Eastern Xinjiang, NW China. Terra Nova 14, 249256.

Laurent-Charvet, S., Charvet, J., Monié, P. and Shu, L.S., 2003. Late Paleozoic strike-slip shear zones in eastern central Asia (NW China): New structural and geochronological data. Tectonics 22, 1009, DOI: 10.1029/2001TC901047

Lawrence, S.R., 1990. Aspects of the petroleum geology of the Junggar basin, Northwest China. Geological Society, London, Special Publications 50, 545-557.

Levashova, N.M., Degtyarev, K.E., Bazhenov, M.L., Collins, A.Q. and Van der Voo, R., $2003 a$. Middle paleozoic paleomagnetism of east Kazakhstan: post-Middle Devonian rotations in a large-scale orocline in the central Ural-Mongol belt. Tectonophysics 377, 249-268.

Levashova, N.M., Degtyarev, K.E., Bazhenov, M.L., Collins, A.Q. and Van der Voo, R., 2003 b. Permian paleomagnetism of East Kazakhstan and the amalgamation of Eurasia. Geophysical Journal International 152, 677-687.

Levashova, N.M., Mikolaichuk, A.V., McCausland, P.J.A., Bazhenov, M.L. and Van der Voo, R., 2007. Devonian paleomagnetism of the North Tien Shan: Implications for the middle-Late Paleozoic paleogeography of Eurasia. Earth and Planetary Science Letters 257, 104-120.

Levashova, N.M., Van der Voo, R., Abrajevitch, A.V. and Bazhenov, M.L., 2009. Paleomagnetism of mid-Paleozoic subduction-related volcanics from the Chingiz Range in NE Kazakhstan: The evolving paleogeography of the amalgamating Eurasian composite continent. Geological Society of America Bulletin 121, 555-573. 
Li, X.Z., Han, B. F., Ji, J. Q., Li, Z. H., Liu, Z. Q., Yang, B., 2004. Geology, geochemistry and KAr ages of the Karamay basic-intermediate dike swarm from Xinjiang, China. Geochimica 33, 574-584.

Li, Y.P., Sharps, R., McWilliams, M., Li, Y. G., Li, Q., Zhang, W., 1991. Late Paleozoic paleomagnetic results from the Junggar Block, Northwestern China. Journal of Geophysical Research-Solid Earth 96, 16047-16060.

Li, Y.P., Sharps, R., McWilliams, M., Nur, A., Li, Y. G., Li, Q., Zhang, W., 1989. Paleomagnetic results from late Paleozoic dikes from the northwestern Junggar Block. Earth and Planetary Science Letters 94, 123-130.

Lowrie, W., 1990. Identification of ferromagnetic minerals in a rock by coercivity and unblocking temperature properties. Geophysical Research Letters 17, 159-162.

Lyons, J.J., Coe, R. S., Zhao, X. X., Renne, P. R., Kazansky, A. Y., Izokh, A. E., Kungurtsev, L. V., Mitrokhin, D. V.2002. Paleomagnetism of the early Triassic Semeitau igneous series, eastern Kazakstan. Journal of Geophysical Research-Solid Earth 107, DOI: 10.1029 /2001JB000521.

Melnikov, A., Delvaux, D., Travin, A., Buslov, M., Vladimirov, A.,Smirnova, L., and Theunissen, K., 1997. Late Paleozoic-EarlyMesozoic sinistral movement along the Irtysh shear zone, NE Kazakhstan. Tectonic studies group annual general meeting, Durham, 17-19 December.

Melnikov, A., Travin, A., Plotnikov, A., Smirnova, L., and Theunissen, K., 1998. Kinematics and Ar/Ar geochronology of the Irtysh shear zone in NE Kazakhstan. In: Continental growth in the Phanerozoic: evidence from East-Central Asia. First workshop, IGCP-420, Urumqi, China, 27 July-3 August, p. 30.

Mikolaichuk, A.V., Kotov, V.V., Kuzikov, S.I., 1995. The structural position of the Malyi Naryn metamorphic complex and the boundary between the North and Middle Tien Shan. Geotectonics 29, 157-166. 
Molnar, P. and Tapponnier, P., 1975. Cenozoic tectonics of Asia: Effects of a continental collision. Science 189, 419-426.

Nie, S.Y., Rowley, D.B., Vandervoo, R. and Li, M.S., 1993. Paleomagnetism of Late Paleozoic rocks in the Tianshan, Northwestern China. Tectonics 12, 568-579.

Qi, J.Y., 1993. Geology and genesis of dike swarms in western Junggar, Xinjiang, China. Acta Petrologica Sinica 9, 288-299.

Samygin, S.G., 1974. The Chingiz Strike-slip Fault and its position in the structure of Central Kazakhstan, Moscow Nauka, pp. 208 (in Russian)

Sengor, A.M.C., Natalin, B.A. and Burtman, V.S., 1993. Evolution of the Altaid tectonic collage and Paleozoic crustal growth in Eurasia. Nature 364, 299-307.

Sengor, A.M.C. and Natalin, B.A., 1996. Paleotectonics of Asia: fragments of synthesis. In: Yin, A., Harrison,M. (Eds.), The Tectonic Evolution of Asia. Cambridge University Press, pp. 486-640.

Sharps, R., Li, Y.P., McWilliams, M. and Li, Y.G., 1992. Paleomagnetic investigation of Upper Permian sediments in the South Junggar Basin. Journal of Geophysical Research-Solid Earth 97, 1753-1765.

Shen, Y.C., Jin, C.W., Qi, J.Y., 1993. Ore-forming model and mechanism of gold mineralization area in west Junggar. In: Tu G. (Ed.), New developments of Solid Earth Sciences of Northern Xinjiang. Science Press, pp. 137-150 (in Chinese).

Song, H.X. et al., 2007. Geological characters of Baogutu porphyry copper deposit in Xinjiang, NW China. Acta Petrologica Sinica 23, 1981-1988 (in Chinese).

Su, Y.P., Tang, H.F., Hou, G.S. and Liu, C.Q., 2006. Geochemistry of aluminous A-type granites along Darabut tectonic belt in West Junggar, Xinjiang. Geochimica 35, 55-67 (in Chinese).

Tang, G.J., Wang, Q., Zhao, Z.H, Wyman, D.A, Chen, H.H., Jia, X.H., Jiang, Z.Q. 2009. Geochronology and geochemistry of the ore-bearing porphyries in the Baogutu area (western 
Junggar) : petrogenesis and their implications for tectonics and $\mathrm{Cu}-\mathrm{Au}$ mineralization. Scientia Geologica Sinica 34, 56-74 (in Chinese).

Travin, A.V., Boven, A., Plotnikov, A.V., Vladimirov, V.G., Theunissen, K., Vladimirov, A.G., Melnikov, A.I., Titov, A.V., 2001. 40Ar/39Ar dating of ductile deformation in the Irtysh shear zone (Eastern Kazakhstan). Geochemistry 12, 1347-1350.

Van der Voo, R., Levashova, N.M., Skrinnik, L.I., Kara, T.V. and Bazhenov, M.L., 2006. Late orogenic, large-scale rotations in the Tien Shan and adjacent mobile belts in Kyrgyzstan and Kazakhstan. Tectonophysics 426, 335-360.

Van der Voo, R., Abrajevitch, A., Bazhenov, M.L., Levashova, N.M., 2008. A Late Paleozoic orocline that developed in the central Asian triangle between the converging Baltica, Siberia and Tarim cratons. $33^{\text {rd }}$ International Geological Congress, Oslo.

Vladimirov, A., Melnikov, A., Travin, A., Plotnikov, A., Smirnova, L., and Theunissen, K., 1998. The Irtysh shear zone in NE Kazakhstan: kinematics and preliminar data on metamorphic conditions and Ar/Ar geochronology. In: Active tectonic continental basin, International Conference, Gent, April 30-May 2, 1998, p. 105.

Wang, B., Faure, M., Cluzel, D., Shu, L. S., Charvet, J., Meffre, S., Ma, Q., 2006. Late Paleozoic tectonic evolution of the northem West Chinese Tianshan Belt. Geodinamica Acta 19, 237247.

Wang, B., Chen, Y., Zhan, S., Shu, L. S., Faure, M., Cluzel, D., Charvet, J., Laurent-Charvet, S., 2007. Primary Carboniferous and Permian paleomagnetic results from the Yili Block (NW China) and their implications on the geodynamic evolution of Chinese Tianshan Belt. Earth and Planetary Science Letters 263, 288-308.

Wang, B., Faure, M., Shu, L., de Jong, K., Charvet, J., Cluzel, D., Jahn, B., Chen, Y., Ruffet, G., 2010. Structural and Geochronological Study of High-Pressure Metamorphic Rocks in the 
Kekesu Section (Northwestern China): Implications for the Late Paleozoic Tectonics of the Southern Tianshan. The Journal of Geology 118, 59-77.

Wartes, M.A., Carroll, A.R. and Greene, T.J., 2002. Permian sedimentary record of the TurpanHami basin and adjacent regions, northwest China: Constraints on postamalgamation tectonic evolution. Geological Society of America Bulletin 114, 131-152.

Windley, B.F., Alexeiev, D., Xiao, W.J., Kroner, A. and Badarch, G., 2007. Tectonic models for accretion of the Central Asian Orogenic Belt. Journal of the Geological Society 164, 31-47.

XBGMR, Geological map (scale 1:200000), Karamay sheet (K-45-19), 1966.

XBGMR, Geological map (scale 1:200000), Urumqi sheet (K-45-4), 1965.

Xiao, W.J., Windley, B. F., Badarch, G., Sun, S., Li, J., Qin, K., Wang, Z. et al., 2004. Paleozoic accretionary and convergent tectonics of the southern Altaids: implications for the growth of Central Asia. Journal of the Geological Society 161, 339-342.

Xiao, W.J., Han, C.M., Yuan, C., Sun, M., Lin, S.F., Chen, H.L., Li, Z.L., Li, J.L., Sun, S., 2008. Middle Cambrian to Permian subduction-related accretionary orogenesis of Northern Xinjiang, NW China: Implications for the tectonic evolution of central Asia. Journal of Asian Earth Sciences 32, 102-117.

Yakubchuk, A., 2004. Architecture and mineral deposit settings of the Altaid orogenic collage: a revised model. Journal of Asian Earth Sciences 23, 761-779.

Yin, A. and Nie, S., 1996. A Phanerozoic palinspastic reconstruction of China and its neighboring regions. In: Yin, A., Harrison,M. (Eds.), The Tectonic Evolution of Asia. Cambridge University Press, pp. 442-485.

Yin, J.Y., Yuan, C., Sun, M., Long, X.P., Zhao, G.C., Geng, H.Y., 2010. Late Carboniferous HighMg dioritic dykes in Western Junggar, NW China: geochemical features, petrogenesis and tectonic implications. Gondwana Research 17, 145-152. 
Zhang, X., 1981, Regional stratigraphic chart of northwestern China, branch of Xinjiang Uygur autonomous region: Beijing, Geological Publishing House, 496 pp. (in Chinese).

Zhang, C. et al., 1993. Implications of Paleozoic ophioloites from Western Junggar, NW China, for the tectonics of Central. Journal of the Geological Society 150, 551-561.

Zhang, J., 2009. Late Paleozoic accretionary tectonics of the eastern part of Western Junggar, Xinjiang: insights from anatomy of the ophiolitic mélange and accretionary complex. $\mathrm{PhD}$ Thesis, Chinese Academy of Science, Beijing (in Chinese).

Zhao, J.M., Liu, G.D., Lu, Z.X., Zhang, X.K. and Zhao, G.Z., 2003. Lithospheric structure and dynamic processes of the Tianshan orogenic belt and the Junggar basin. Tectonophysics 376, 199-239.

Zhao, X.X., Coe, R.S., Zhou, Y.X., Wu, H.R. and Wang, J., 1990. New paleomagnetic results from Northern China - Collision and suturing with Siberia and. Tectonophysics 181, 43-81.

Zhou, T.F., Yuan, F., Tan, L.G., Fan, Y. and Yue, S.C., 2006. Geodynamic significance of the Atype granites in the Sawuer region in west Junggar, Xinjiang: Rock geochemistry and SHRIMP zircon age evidence. Science in China Series D-Earth Sciences 49, 113-123.

Zhou, J. et al., 2008. Ar-40/Ar-39 Geochronology of mafic dykes in north Xinjiang. Acta Petrologica Sinica 24, 997-1010 (in Chinese).

Zhou, D., Graham, S.A., Chang, E.Z., Wang, B. and Hacker, B., 2001. Paleozoic tectonic amalgamation of the Chinese Tian Shan: Evidence from a transect along the Dushanzi-Kuqa Highway. Paleozoic and Mesozoic tectonic evolution of central Asia: from continental assembly to intracontinental deformation 194, 23-46.

Zijderveld, J.D.A., 1967. A.C. demagnetization of rocks: analysis of results. In: Collinson, D.W., Creer, K.M., Runcorn, S.K. (Eds.), Methods on Paleomagnetism. Elsevier, pp. 245-286. 


\section{Table and Figure captions}

Figure 1 a) Location of the Central Asian Fold Belt in Eurasia (after Van der Voo et al., 2006). b) Map of West Central Asia, including major belts and tectonic features (modified after Charvet et al., 2007 and Windley et al., 2007). Thick solid lines denote major shear zone with their main kinematics. Abbreviations correspond to: BO: Bole; CANTF: ChingizAlakol-North Tian Shan Fault; CH: Chingiz; CKF: Central Kazakhstan Fault; CS: ChuSarysu; IGSZ: Irtysh-Gornotsaev Shear Zone; IMT: Ishim Middle Tian Shan; KT: Karatau; MTF: Main Tian Shan Fault; NNTL: Nikolaiev-Nalati Tectonic Line; NR: Naryn; SB: Shaburt Mountains; SNT: Stepnyak-North Tian Shan; TFF: Talas-Fergana Fault; TN: Teniz; YI: Yili; ZS Zharma Sawuer.

Figure 2 Map (a), cross section (b) and stratigraphic chart (c) of the Northwestern Bogdashan (South Junggar) simplified after XBGRM (1965), with stratigraphic chart after Carroll et al. (1995) and Wartes et al. (2002). Reference number (REF 1-4) is the same than those in the caption of the map of Figure 2a.

Figure 3 Location (a) and map (b) of eastern part of the West Junggar Mountains, modified after XBGRM (1966).

Figure 4 Results of Isothermal Remanence of the Magnetism (IRM, a, d), Lowrie Test (b, e) and thermomagnetic Curie temperature analysis (c-f) of samples from South Junggar and West Junggar. $\mathrm{HC}$ and $\mathrm{CC}$ are the heating and cooling curves respectively.

Figure 5 Measurement results from Early and Late Permian rocks of South Junggar (a, b):Orthogonal projection of sample demagnetization (Zijderveld, 1967) in stratigraphic coordinates. White and black circles represent vertical and horizontal plans respectively. (c-f): Equalarea projection for site-mean directions isolated from high temperature and high coercive 
AF components in geographic (c, e) and stratigraphic $(\mathrm{d}, \mathrm{f})$ coordinates. Stars represent the locality-mean directions.

Figure 6 Measurement results from Early Carboniferous rocks of West Junggar Mountains (for 9 sites: a, c and d and for 5 sites: b, e and f) (a, b):Orthogonal projection in geographic coordinates. (c, d, e, f): Equal-area stereoplots for site-mean directions isolated from high temperature and hard AF components.

Figure 7 AMS study of rocks of South Junggar and West Junggar. a) Plots of anisotropy degree $\left(\mathrm{P}^{\prime}\right)$ versus anisotropy shape (T) of magnetic susceptibility. $P^{\prime}=\exp \left\{2\left[\left(\ln K_{1}-\ln K_{m}\right)^{2}+\left(\ln K_{2}\right.\right.\right.$ $\left.\left.\left.-\ln K_{m}\right)^{2}+\left(\ln K_{3}-\ln K_{m}\right)^{2}\right]^{1 / 2}\right\}$, and $T=2 \ln \left(K_{2} / K_{3}\right) / \ln \left(K_{1} / K_{3}\right)-1$, where $\mathrm{K}_{1}, \mathrm{~K}_{2}$ and $\mathrm{K}_{3}$ are the principal axes of the magnetic fabrics and $\mathrm{K}_{\mathrm{m}}$ is the average of them. (b) Stereoplot of $\mathrm{K}_{1}, \mathrm{~K}_{2}$ and $\mathrm{K}_{3}$, (open and filled circles correspond to data and their means, respectively.

Figure 8 a): Laminated mudstone transformed into hornfels from the vicinity of Miaoergou pluton of West Junggar. b): Prehnite and pumpellyite from greywacke of West Junggar. c): Synthesis of geochronological data from magmatic Late Paleozoic rocks of West Junggar, after Kwon et al. (1989), Jin and Shen (1993), Qi et al. (1993), Shen et al. (1993), Li et al. (2004), Chen and Arakawa (2005), Han et al. (2006), Su et al. (2006), Zhou et al. (2006), Song et al. (2007), Wang and Zhu (2007), Zhou et al. (2008), An and Zhu (2009), Geng et al. (2009), Tang et al. (2009), Zhang et al. (2009) and Yin et al. (2010).

Figure 9 a-c): Equal-area projections of Late Paleozoic poles of West Junggar, South Junggar and North Kazakhstan, respectively. d-e): Equal-area projections of Late Carboniferous-Early Permian $\left(\mathrm{C}_{3}-\mathrm{P}\right)$ and Late Permian $\left(\mathrm{P}_{2}\right)$ mean poles of West Junggar block (WJG), South Junggar block (SJG), North Kazakhstan block (NKZ), Siberia (SIB), Yili (YI) and Tarim (TAR), respectively, showing the amount of relative rotation and latitudinal movement between these blocks. Open stars represent the sampling location. Small circle centred on this location and passing through poles reveals large discrepancies in declination 
(subsequent rotation) and weak difference in paleolatitude (subsequent N-S movements) of blocks.

Figure 10 Sketch of Western Central Asia showing post-Upper Permian displacements, Euler poles and tectonic boundaries (NNTL: Nikolaiev-Nalati Tectonic Line; CANTF: ChingizAlakol-North Tian Shan Fault; IGSZ: Irtysh-Gornotsaev Shear Zone and Jg: Junggar Basin). Relative rotations (with uncertainties) between tectonic blocks are recalculated at the coordinates of the corresponding Eular pole and listed in Table 4. Kinematics and time brackets on the strike-slip faults are also mentioned.

Figure 11 Tentative reconstruction of four stages of the geodynamic evolution of Eastern Central Asia since Carboniferous (after Van der Voo et al., 2008). a), At $340 \mathrm{Ma}$, subduction of Junggar and Ob-Zaisan oceans under Kazakhstan, Tian Shan and Altai. Oroclinal bending process is active since Devonian in Kazakhstan; b), At 300 Ma, subduction is limited to the inner part of the orocline in Central Kazakhstan (Filippova et al., 2001; Windley et al., 2007). Collision between West Junggar, Junggar and Siberia, with subsequent rotation. At this time Strike-slip faults are inititited in Altai, Kazakhstan and Tian Shan; c), At 260 Ma, subduction process is complete, but significant relative rotations between the blocks are recorded along major shear zones; and d), Present setting resulting from the continuity of the rotational movements in Early Mesozoic and the post-Paleozoic reactivation of the belts. Abbreviations: ANTF: Alakol-North Tian Shan Fault; CF: Chingiz Fault; CKF: Central Kazakhstan Fault; GF: Gornotsaev Fault; IF:Irtysh Fault; MTF: Main Tian Shan Fault; NNTL: Nikolaev-Nalati Tectonic Line; SF: Sangshuyanzhi Fault.

Table 1 Results of the paleomagnetic measurements. Abbreviations: n, number of measured samples; N, number of collected samples; P, polarity; R, reversed; $\mathrm{P}_{1 \text { t }}$, Early Permian Tashikula Formation (Fm); $\mathrm{P}_{2 \mathrm{j}}$, Late Permian Wulapo Fm; $\mathrm{P}_{2 \mathrm{j} n}$, Late Permian Jingjingzigou Fm; $\mathrm{C}_{1 \mathrm{x}}$, Early Carboniferous Xibeikulasi Fm; $\mathrm{C}_{1 \mathrm{t}}$, Early Carboniferous Tailegula Fm; *, 
the age of remanence in parentheses; Dg, Ig, Ds and Is, declination (D) and inclination (I) in geographic ( $\mathrm{g}$ ) and stratigraphic (s) coordinates; $\mathrm{k}$, the precision parameter, $\alpha_{95}$, the radius that the mean direction lies within $95 \%$ confidence.

Table 2 Compilation of Late Paleozoic data of Western Central Asia. Abbreviations: N, the number of sites; Slat (Plat), the latitude of site (pole); Slong (Plong), the longitude of site (pole); \# $\mathrm{REF}$, the reference number; $\mathrm{A}_{95}$, the radius that mean direction lies within $95 \%$ confidence; $\mathrm{dp}$ and $\mathrm{dm}$, the two axes of an oval of confidence with 95\%. a, important uncertainties on the bedding surface; b, 52 out of 78 samples analysed with great circle method; c, Pole recalculated after cancelling isolated site 42 of Nie et al. (1993); d: mafic dykes sampled without control on the initial setitng; e, deviation of the declination due to local rotation along the Chingiz Fault; f: overstep post-folding inclination, with unknown origin. The paleomagnetic poles denoted by $*$ are eliminated from the average. All poles available in literature were recalculated from paleomagnetic directions and some values could differ from those given by reference papers

Table 3 Compilation of Late Paleozoic relative movements between West Junggar, North Kazakhstan, Siberia, Yili, South Junggar and Tarim; ANG $\pm \Delta \mathrm{ANG}, \mathrm{ROT} \pm \Delta \mathrm{ROT}$ and Plat $\pm \Delta$ Plat correspond to angular difference between paleopoles, relative rotation and latitudinal displacement (and their error limit) between blocks, respectively. Errors were computed by using the conversion factor of 0.78 (Demarest, 1983; Coe et al., 1985). Relative movements between the blocks are computed by using average sites at $45.3^{\circ} \mathrm{N}$, $84.0^{\circ} \mathrm{E}$ and $43.8^{\circ} \mathrm{N}, 87.8^{\circ} \mathrm{E}$ for West Junggar and South Junggar, respectively.

Table 4 Relative displacements between Siberia, South Junggar and Tarim. "P2" corresponds to the displacement since Late Permain, whereas "C2 to P2", corresponds to the displacement 
between Late Carboniferous and Late Permian. The radius column corresponds to the radius of a circle, centred on the Euler pole and intercepting major blocks boundary. 


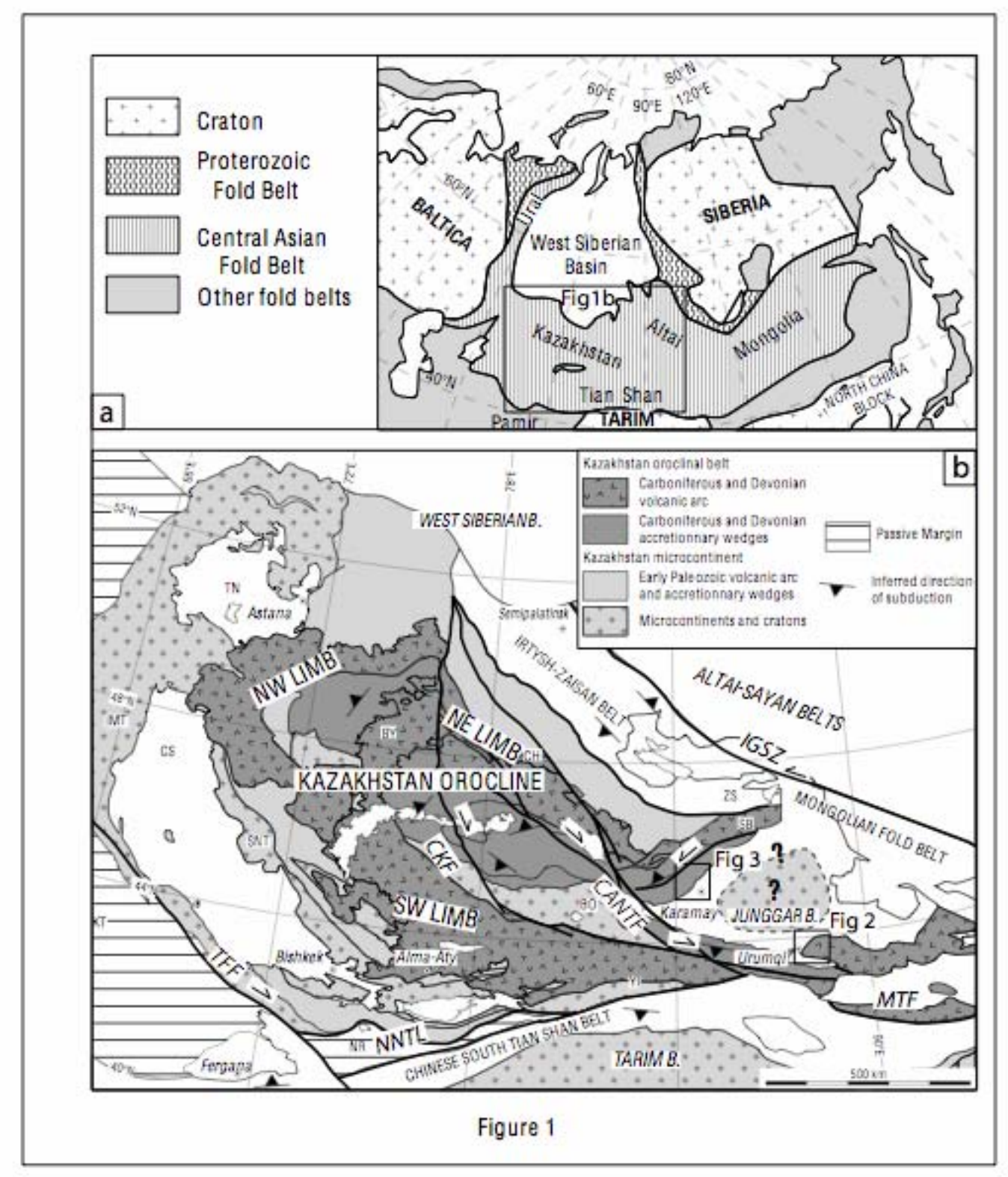




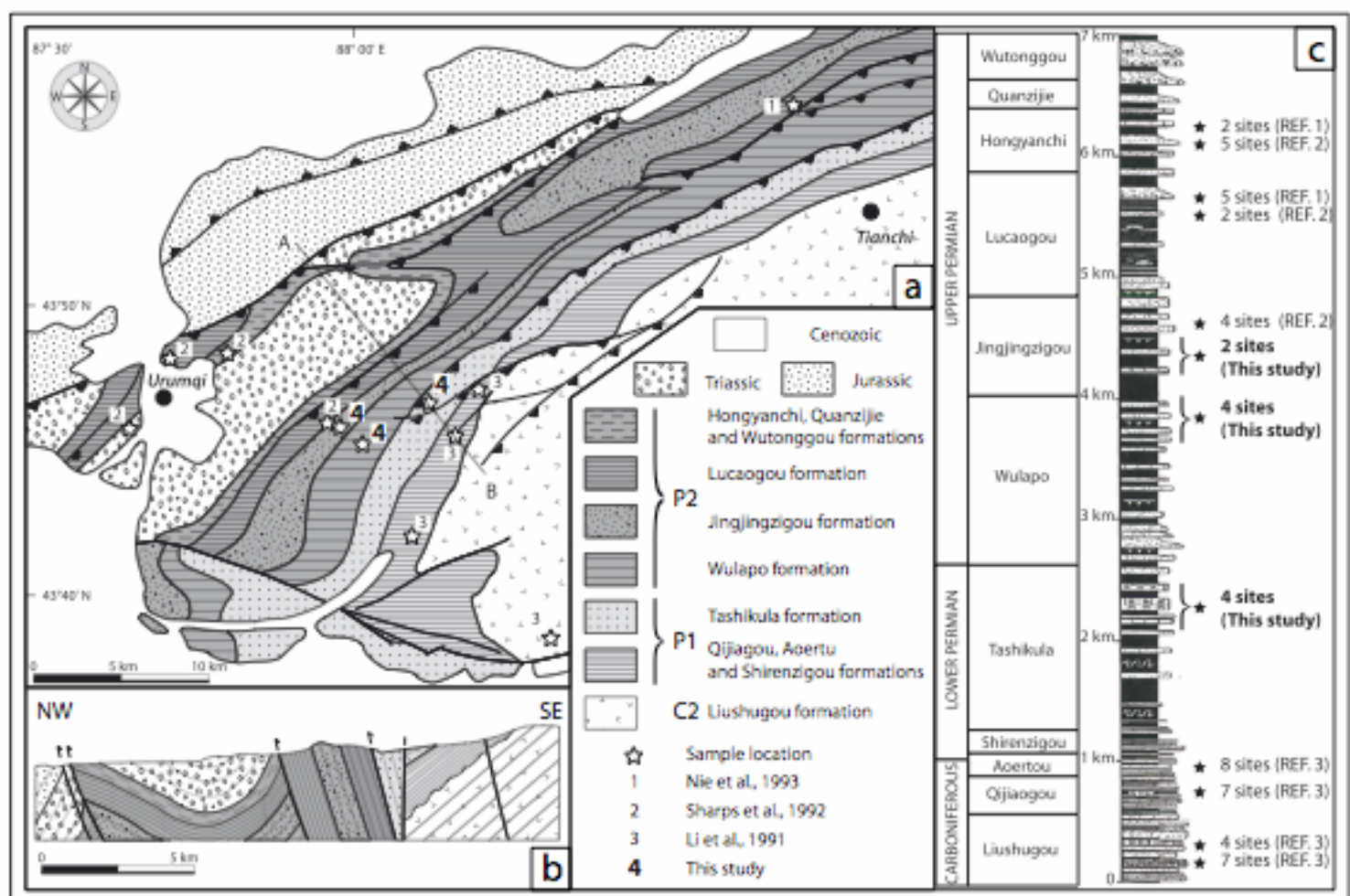

Figure 2 


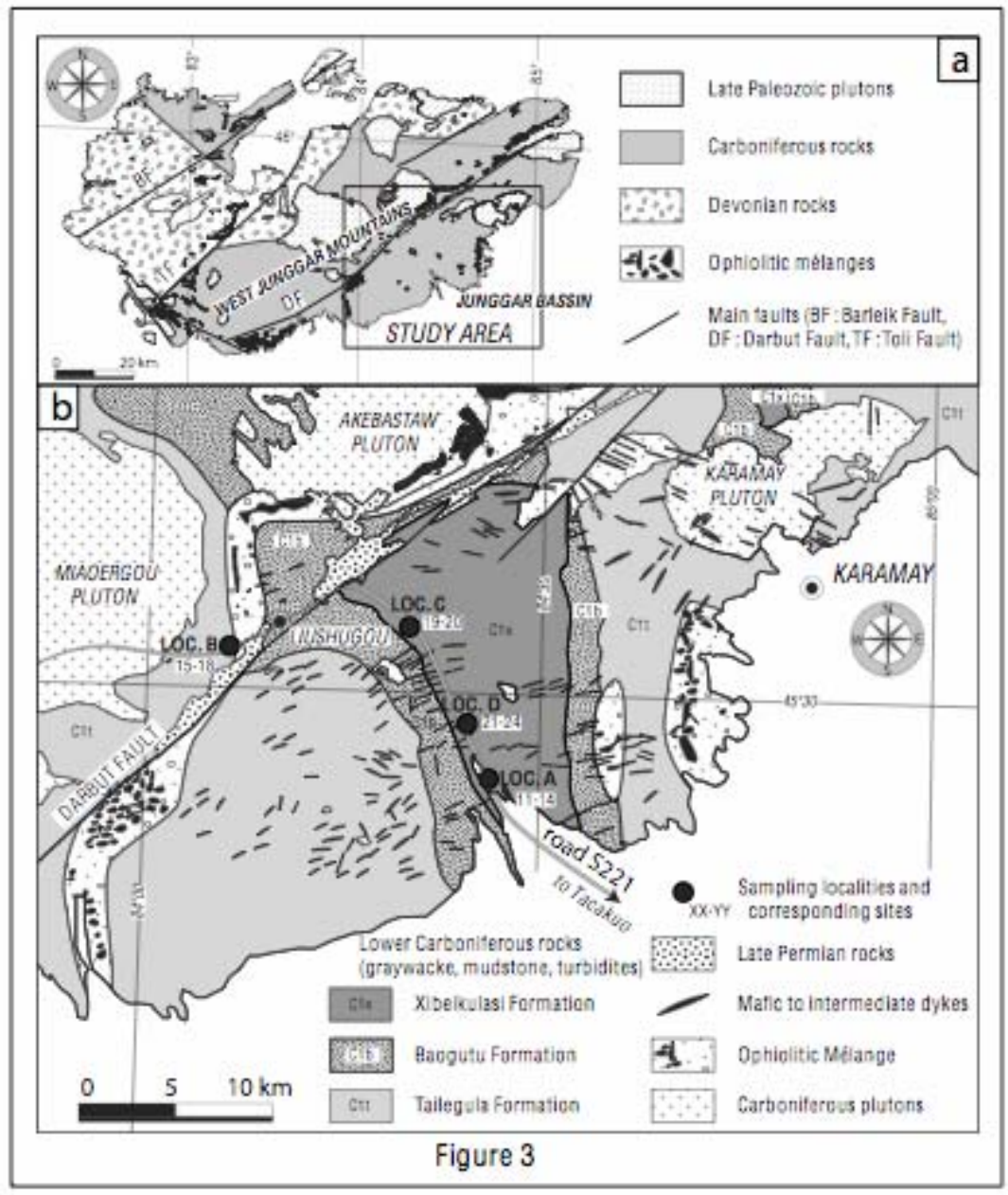




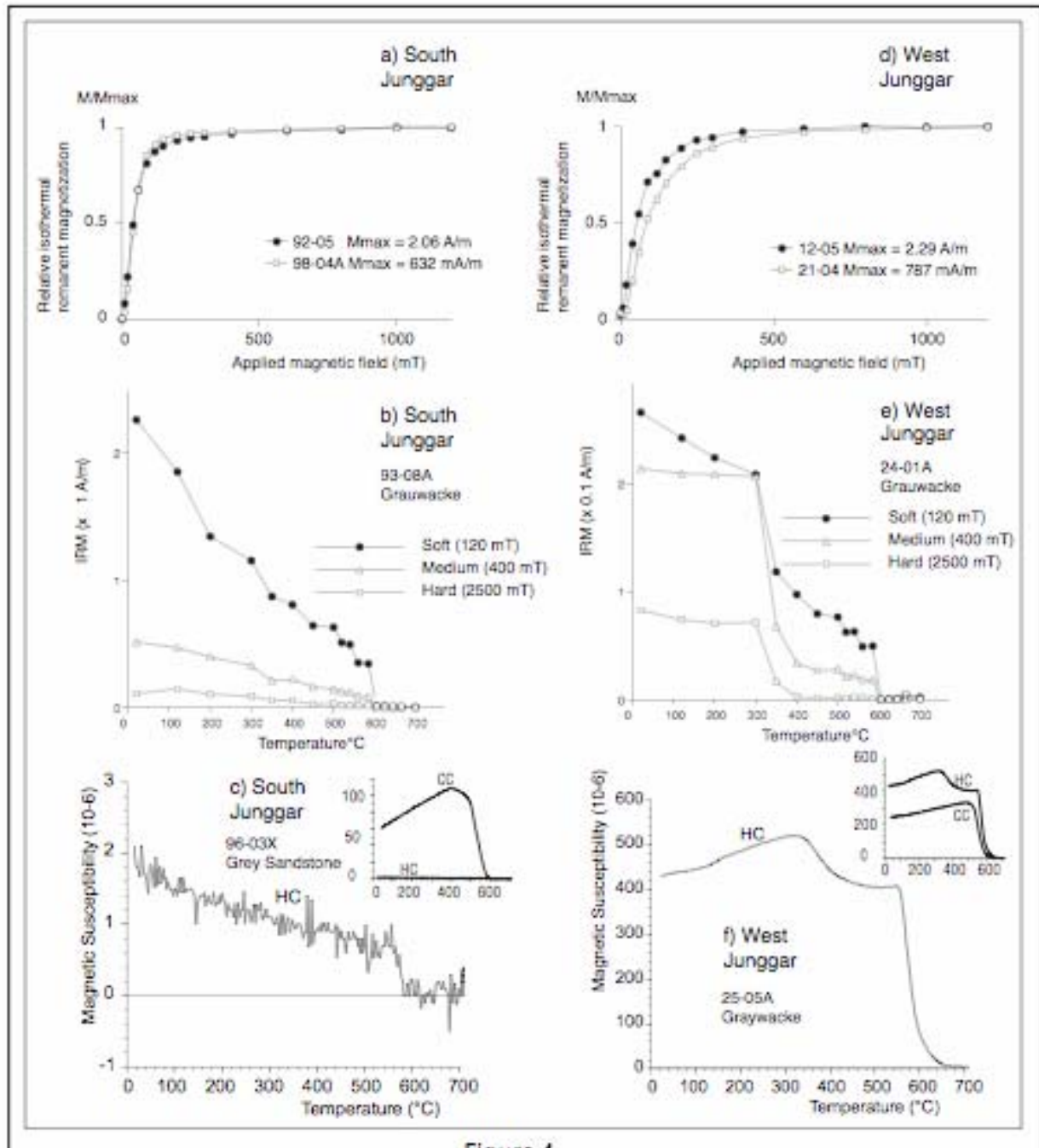

Figure 4 


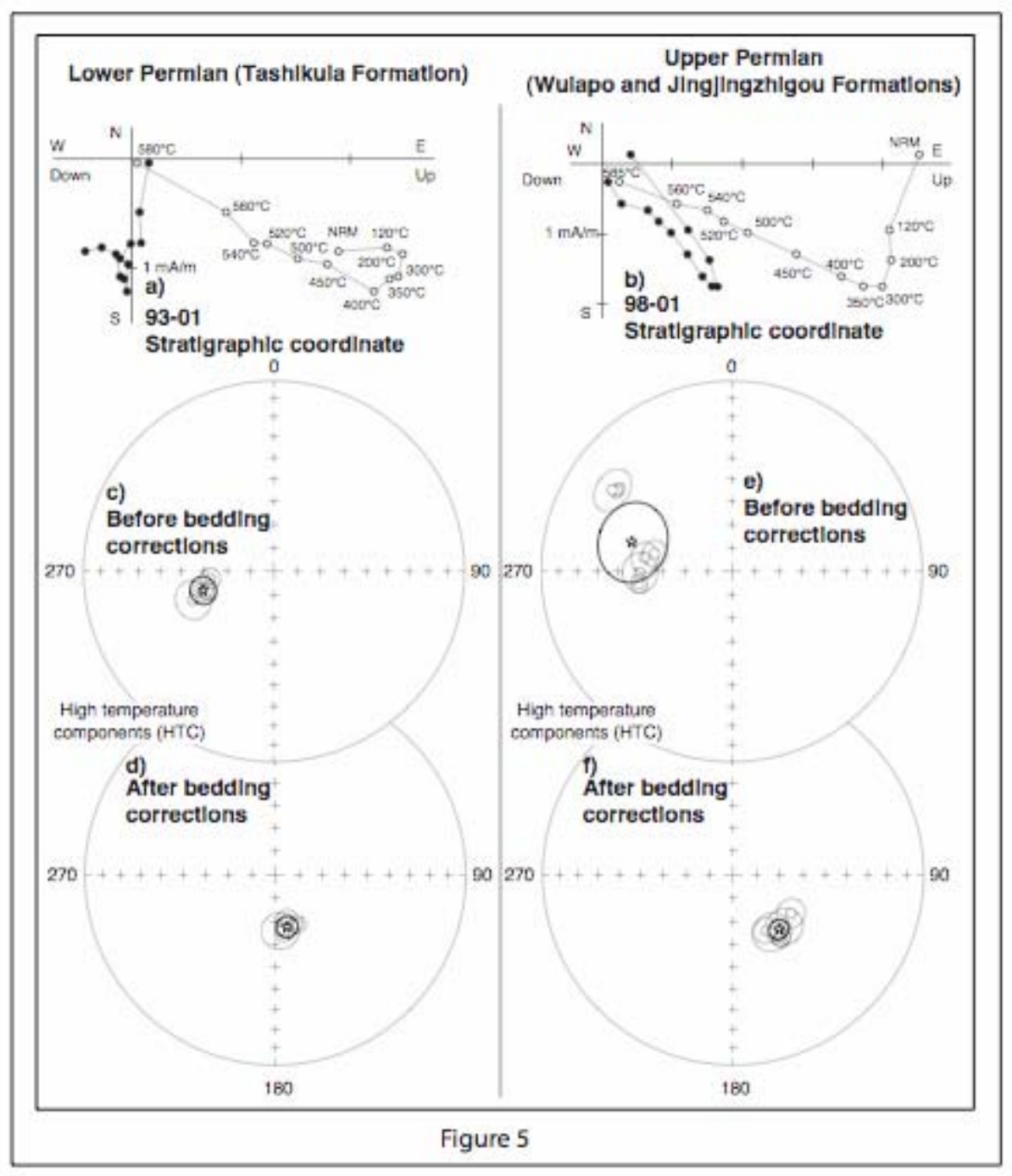




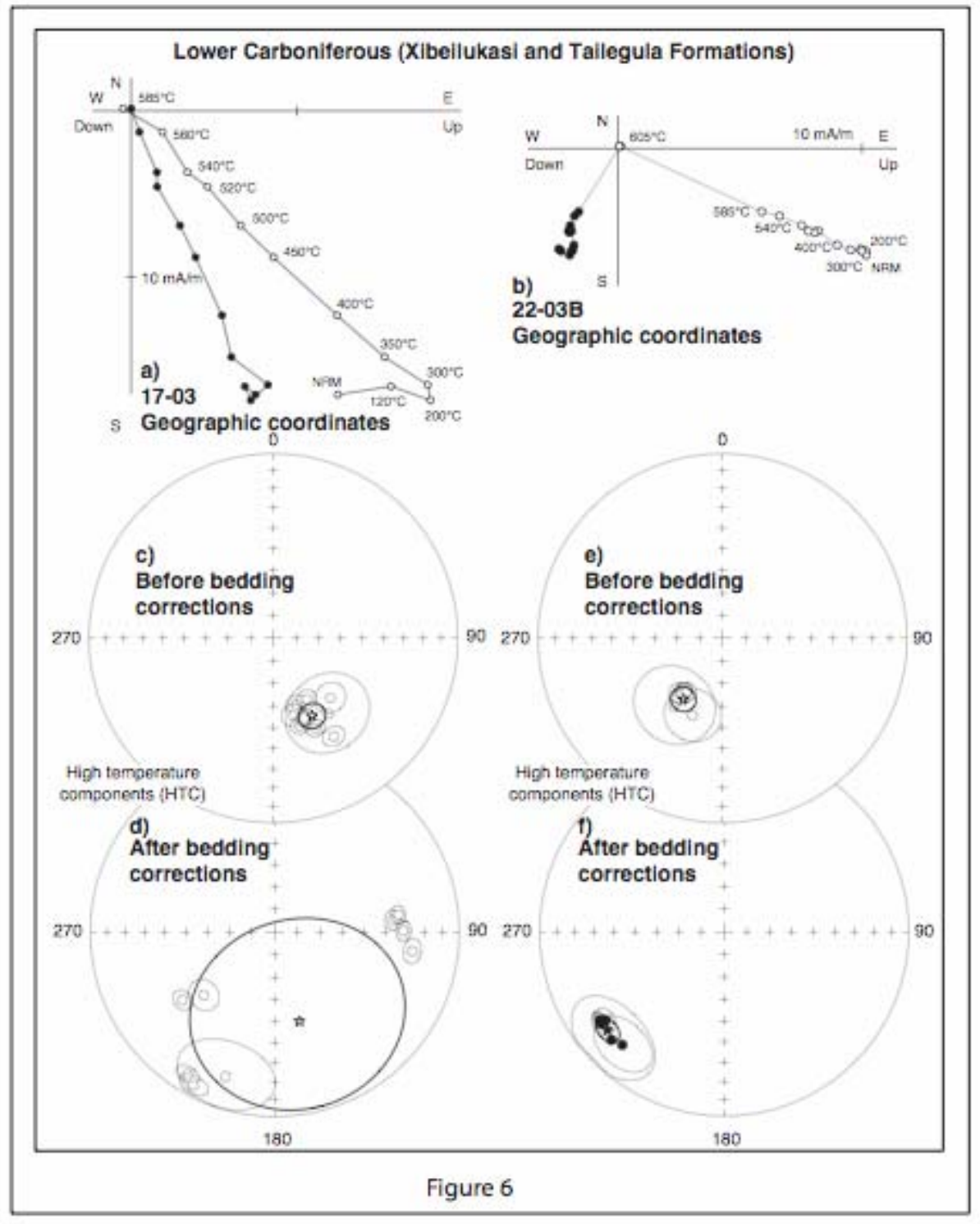




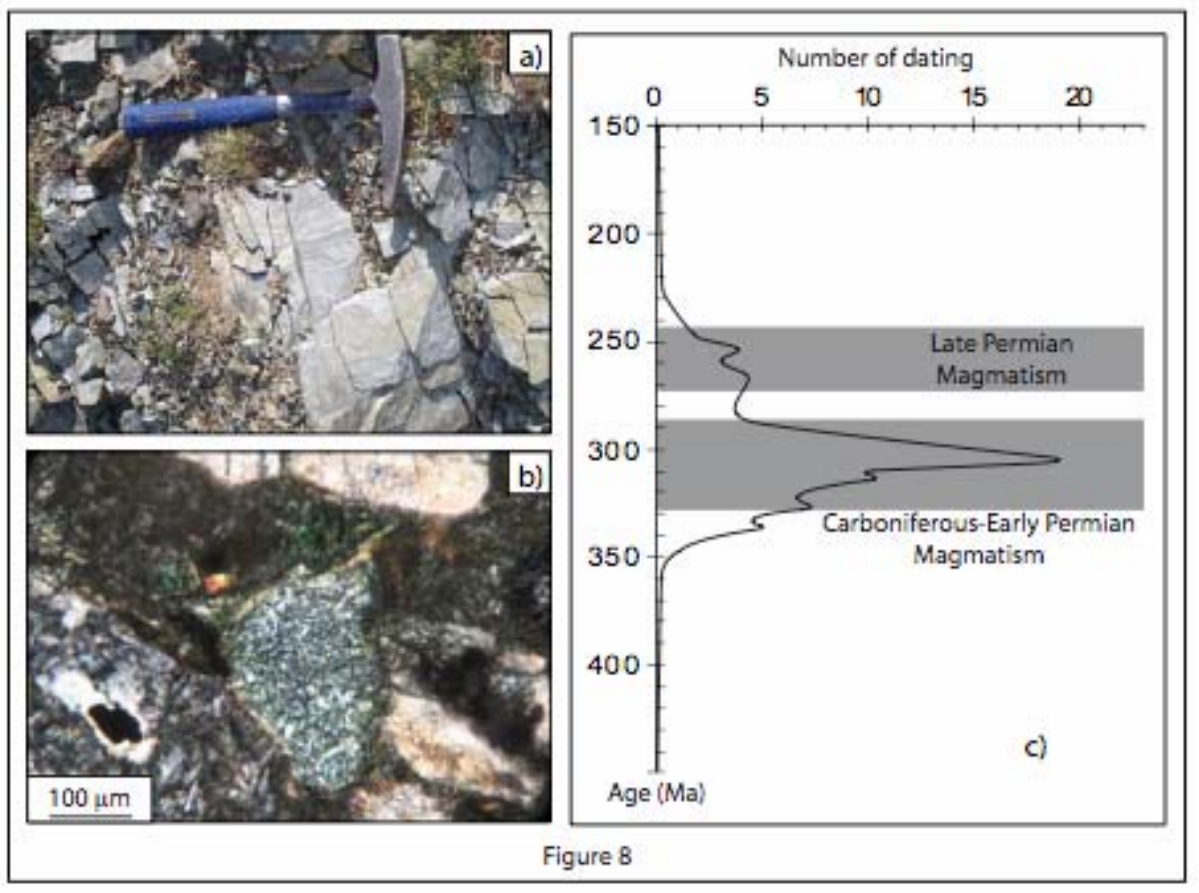




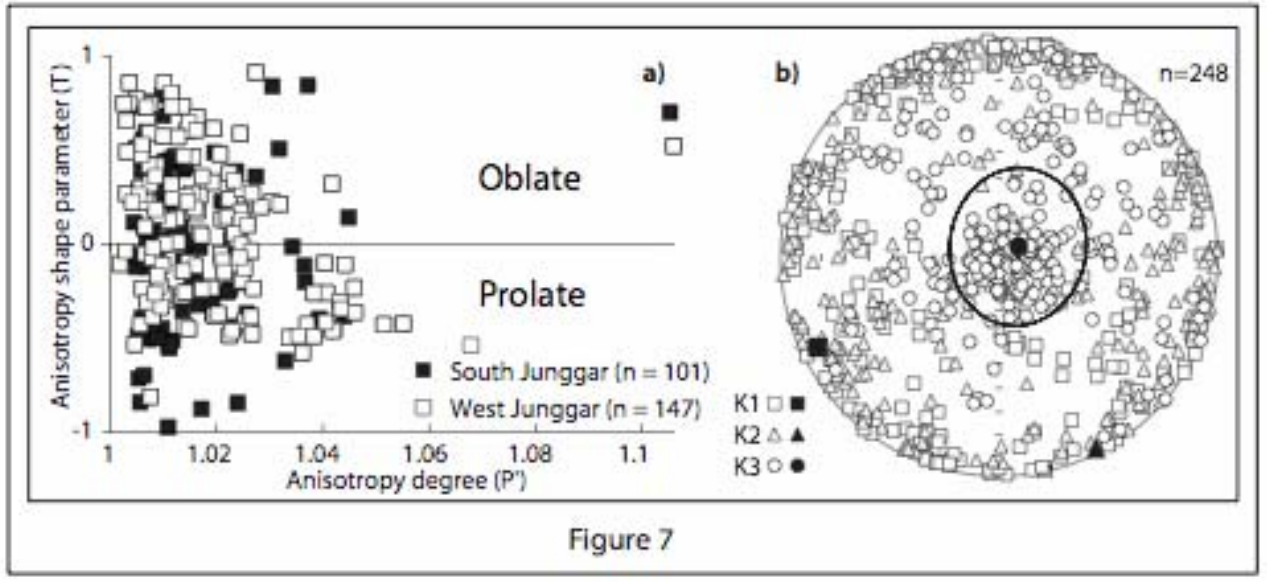




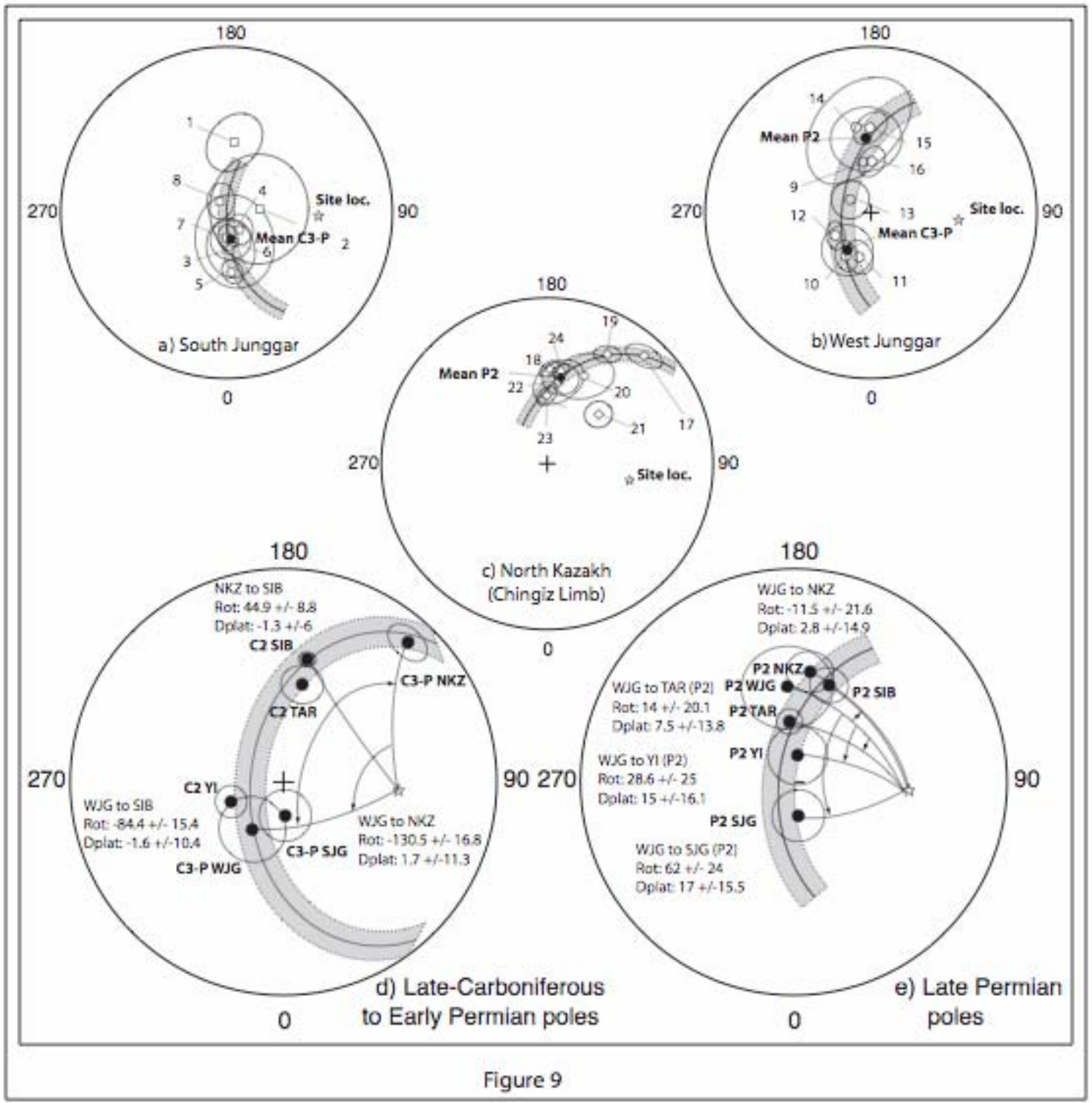




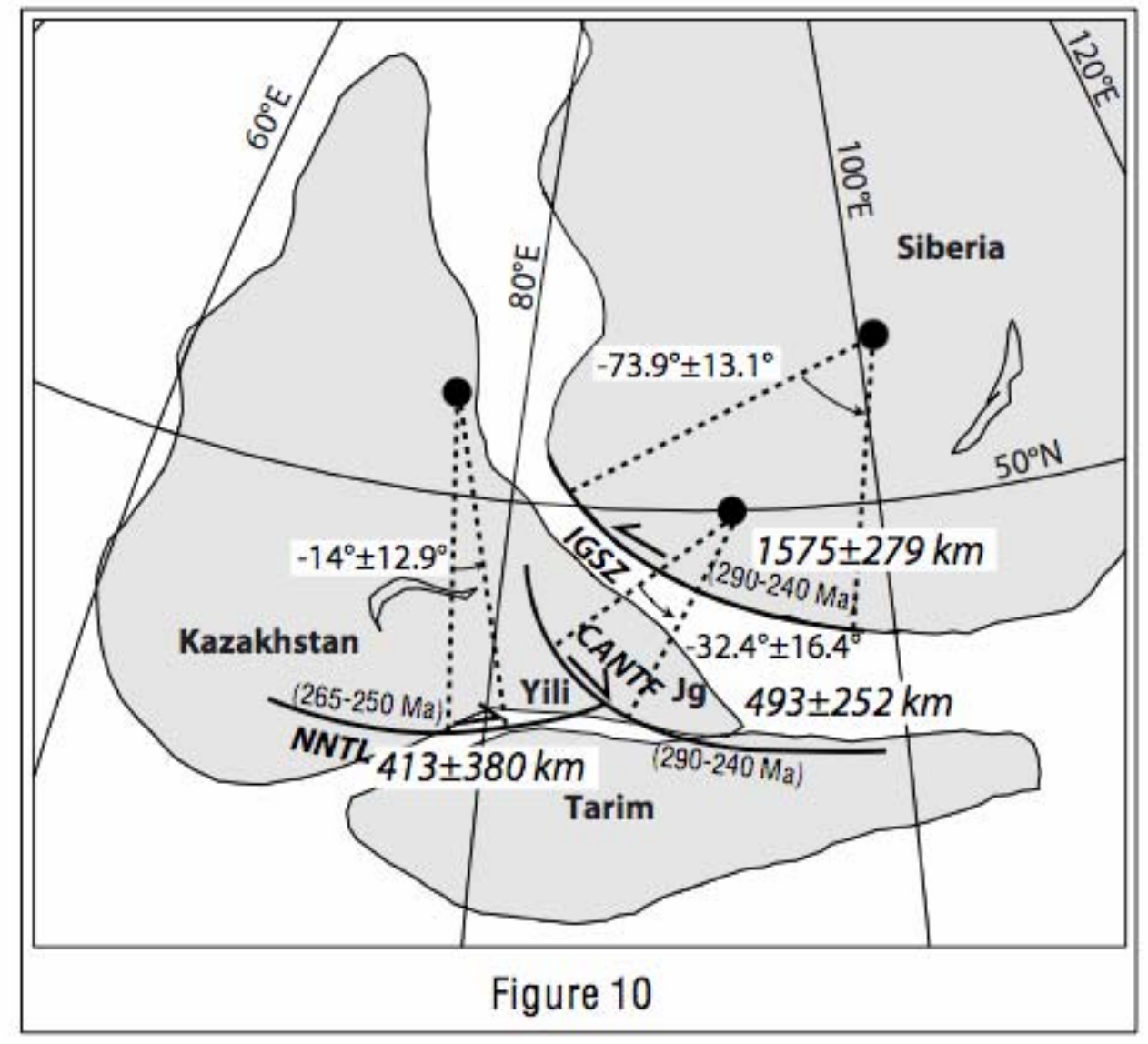




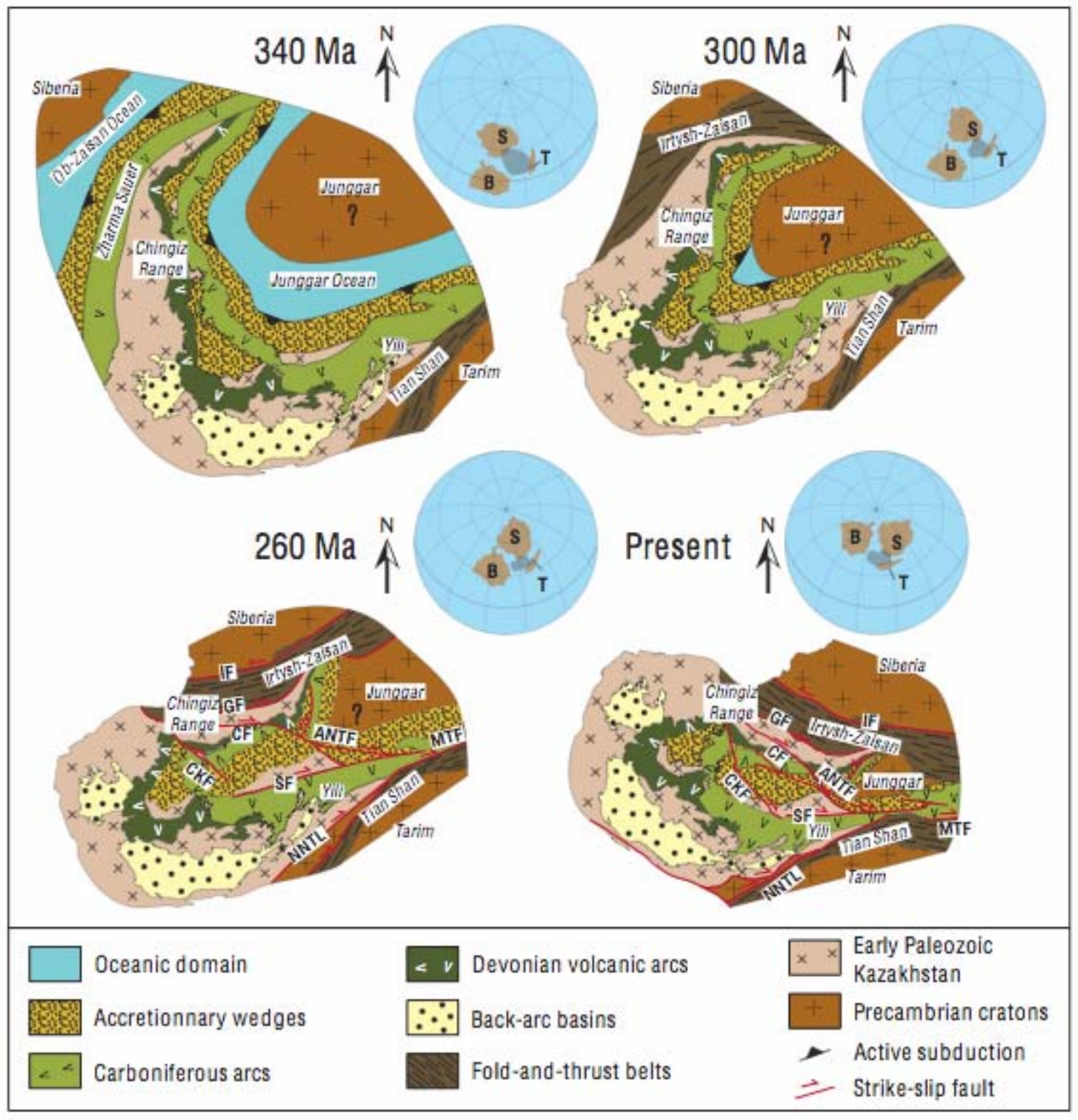

Figure 11 


\begin{tabular}{|c|c|c|c|c|c|c|c|c|c|c|c|c|}
\hline Site & Coordinates & Rocks & Age & Strike/ Dip & $n / N$ & $\mathbf{P}$ & Dg & Ig & Ds & IS & $\mathbf{k}$ & $\alpha 95$ \\
\hline \multicolumn{13}{|l|}{$\begin{array}{l}\text { Urumqi } \\
\text { area }\end{array}$} \\
\hline DP92 & $43.8^{\circ} \mathrm{N}, 87.8^{\circ} \mathrm{E}$ & Grey sandstones & P1t & $207 / 37$ & $7 / 8$ & $\mathrm{R}$ & 263.5 & -62.5 & 165.5 & -70.1 & 187.8 & 4.4 \\
\hline DP93 & $43.8^{\circ} \mathrm{N}, 87.8^{\circ} \mathrm{E}$ & Grey sandstones & P1t & $205 / 40$ & $7 / 8$ & $\mathrm{R}$ & 253.8 & -57.6 & 171.4 & -64.9 & 247.4 & 3.8 \\
\hline DP94 & $43.8^{\circ} \mathrm{N}, 87.8^{\circ} \mathrm{E}$ & Dark siltsones & P1t & $199 / 41$ & $8 / 8$ & $\mathrm{R}$ & 250.4 & -52.8 & 175.2 & -65.7 & 49.7 & 7.9 \\
\hline DP95 & $43.8^{\circ} \mathrm{N}, 87.8^{\circ} \mathrm{E}$ & Dark siltsones & P1t & 199/41 & $8 / 9$ & $\mathrm{R}$ & 253.1 & -60.3 & 156.4 & -66.8 & 235.6 & 3.6 \\
\hline \multirow[t]{2}{*}{ Mean } & & & & & 4 & $\mathbf{R}$ & 254.8 & -58.4 & & & 255.2 & 5.8 \\
\hline & & & & & & & & & 167.4 & -67.0 & 417.5 & 4.5 \\
\hline DP96 & $43.8^{\circ} \mathrm{N}, 87.8^{\circ} \mathrm{E}$ & Dark siltsones & $P 2 j$ & $200 / 67$ & $6 / 9$ & $\mathrm{R}$ & 269.3 & -50.1 & 135.7 & -58.4 & 71.8 & 8.0 \\
\hline DP97 & $43.8^{\circ} \mathrm{N}, 87.8^{\circ} \mathrm{E}$ & Dark siltsones & $P 2 j$ & $200 / 67$ & $8 / 9$ & $\mathrm{R}$ & 262.2 & -49.4 & 142.6 & -55.7 & 217.2 & 3.8 \\
\hline DP98 & $43.8^{\circ} \mathrm{N}, 87.8^{\circ} \mathrm{E}$ & $\begin{array}{l}\text { Siltsones and } \\
\text { sandstones }\end{array}$ & $P 2 j$ & $200 / 67$ & $8 / 8$ & $\mathrm{R}$ & 278.9 & -51.7 & 123.8 & -60.1 & 80.4 & 6.2 \\
\hline DP99 & $43.8^{\circ} \mathrm{N}, 87.8^{\circ} \mathrm{E}$ & Dark siltsones & $P 2 j$ & $214 / 58$ & $8 / 14$ & $\mathrm{R}$ & 283.0 & -55.9 & 149.3 & -62.0 & 103.6 & 5.5 \\
\hline DP101 & $43.8^{\circ} \mathrm{N}, 87.8^{\circ} \mathrm{E}$ & $\begin{array}{l}\text { Siltsones and } \\
\text { sandstones }\end{array}$ & P2jn & $222 / 94$ & $5 / 8$ & $\mathrm{R}$ & 305.4 & -27.4 & 143.1 & -58.0 & 648.5 & 3.0 \\
\hline DP102 & $43.8^{\circ} \mathrm{N}, 87.8^{\circ} \mathrm{E}$ & $\begin{array}{l}\text { White } \\
\text { sandstones }\end{array}$ & P2jn & $222 / 94$ & $8 / 10$ & $\mathrm{R}$ & 304.3 & -25.0 & 146.1 & -60.1 & 45.6 & 8.3 \\
\hline \multirow[t]{2}{*}{ Mean } & & & & & 6 & $\mathbf{R}$ & 286.4 & -44.6 & & & 18.6 & $\begin{array}{l}16 . \\
0\end{array}$ \\
\hline & & & & & & & & & 140.1 & -59.3 & 253.9 & 4.2 \\
\hline \multicolumn{13}{|c|}{$\begin{array}{l}\text { Karamay } \\
\text { area }\end{array}$} \\
\hline DP11 & $45.4^{\circ} \mathrm{N}, 84.4^{\circ} \mathrm{E}$ & Graywackes & $\begin{array}{l}\mathrm{C} 1 \mathrm{x} \\
\text { (C3-P) } \\
*\end{array}$ & $359 / 62$ & $7 / 8$ & $\mathrm{R}$ & 160.9 & -58.7 & 211.5 & -10.5 & 200.0 & 4.3 \\
\hline DP12 & $45.4^{\circ} \mathrm{N}, 84.4^{\circ} \mathrm{E}$ & Graywackes & $\begin{array}{l}\text { C1x } \\
\text { (C3-P) }\end{array}$ & $359 / 62$ & $6 / 8$ & $\mathrm{R}$ & 165.3 & -54.3 & 208.0 & -6.8 & 165.9 & 5.2 \\
\hline DP14 & $45.4^{\circ} \mathrm{N}, 84.4^{\circ} \mathrm{E}$ & Graywackes & $\begin{array}{l}\text { C1x } \\
(C 3-P)\end{array}$ & $359 / 62$ & $5 / 8$ & $\mathrm{R}$ & 144.1 & -48.0 & 198.8 & -18.4 & 18.7 & $\begin{array}{l}18 . \\
1\end{array}$ \\
\hline DP15 & $45.5^{\circ} \mathrm{N}, 84.1^{\circ} \mathrm{E}$ & Graywackes & $\begin{array}{l}\text { C1t } \\
\text { (C3-P) }\end{array}$ & $131 / 70$ & $8 / 8$ & $\mathrm{R}$ & 163.1 & -49.0 & 84.3 & -35.9 & 202.3 & 3.9 \\
\hline DP16 & $45.5^{\circ} \mathrm{N}, 84.1^{\circ} \mathrm{E}$ & Graywackes & $\begin{array}{l}\text { C1t } \\
\text { (C3-P) }\end{array}$ & $131 / 70$ & $5 / 9$ & $\mathrm{R}$ & 158.9 & -51.3 & 82.1 & -32.8 & 449.2 & 3.6 \\
\hline DP17 & $45.5^{\circ} \mathrm{N}, 84.1^{\circ} \mathrm{E}$ & Graywackes & $\begin{array}{l}\text { C1t } \\
\text { (C3-P) }\end{array}$ & $131 / 70$ & $7 / 8$ & $\mathrm{R}$ & 155.0 & -45.3 & 89.5 & -30.8 & 240.5 & 3.9 \\
\hline DP18 & $45.5^{\circ} \mathrm{N}, 84.1^{\circ} \mathrm{E}$ & Graywackes & $\begin{array}{l}\text { C1t } \\
\text { (C3-P) }\end{array}$ & $131 / 70$ & $8 / 8$ & $\mathrm{R}$ & 148.5 & -37.6 & 97.9 & -25.6 & 140.6 & 4.7 \\
\hline DP19 & $45.3^{\circ} \mathrm{N}, 84.3^{\circ} \mathrm{E}$ & Graywackes & $\begin{array}{l}\text { C1x } \\
\text { (C3-P) }\end{array}$ & $359 / 62$ & $6 / 8$ & $\mathrm{R}$ & 136.3 & -53.1 & 228.4 & -47.3 & 98.1 & 6.8 \\
\hline DP20 & $45.3^{\circ} \mathrm{N}, 84.3^{\circ} \mathrm{E}$ & Graywackes & $\begin{array}{l}\text { C1x } \\
(C 3-P)\end{array}$ & $359 / 62$ & $7 / 8$ & $\mathrm{R}$ & 151.4 & -58.9 & 233.6 & -37.8 & 199.7 & 4.3 \\
\hline \multirow[t]{2}{*}{ Mean } & & & & & 9 & $\mathbf{R}$ & 153.5 & -51.0 & & & 81.6 & 5.7 \\
\hline & & & & & & & & & 164.4 & -48.4 & 2.2 & $\begin{array}{l}45 \\
8\end{array}$ \\
\hline DP13 & $45.4^{\circ} \mathrm{N}, 84.4^{\circ} \mathrm{E}$ & Graywackes & $\begin{array}{l}\mathrm{C} 1 \mathrm{x} \\
(\mathrm{P} 2)\end{array}$ & $359 / 62$ & $5 / 8$ & $\mathrm{R}$ & 215.6 & -52.7 & 226.1 & 16.4 & 19.7 & $\begin{array}{l}17 . \\
7\end{array}$ \\
\hline DP21 & $45.5^{\circ} \mathrm{N}, 84.4^{\circ} \mathrm{E}$ & Graywackes & $\begin{array}{l}\text { C1x } \\
(\mathrm{P} 2)\end{array}$ & $341 / 85$ & $5 / 9$ & $\mathrm{R}$ & 217.0 & -61.6 & 234.7 & 18.4 & 573.9 & 3.2 \\
\hline DP22 & $45.5^{\circ} \mathrm{N}, 84.4^{\circ} \mathrm{E}$ & Graywackes & $\begin{array}{l}\mathrm{C} 1 \mathrm{x} \\
(\mathrm{P} 2)\end{array}$ & $341 / 85$ & $5 / 8$ & $\mathrm{R}$ & 217.5 & -58.8 & 233.2 & 20.8 & 261.1 & 4.7 \\
\hline DP23 & $45.5^{\circ} \mathrm{N}, 84.4^{\circ} \mathrm{E}$ & Graywackes & $\begin{array}{l}\mathrm{C} 1 \mathrm{x} \\
(\mathrm{P} 2)\end{array}$ & $341 / 85$ & $4 / 8$ & $\mathrm{R}$ & 201.2 & -52.9 & 222.0 & 18.5 & 58.3 & $\begin{array}{l}12 . \\
1\end{array}$ \\
\hline DP24 & $45.5^{\circ} \mathrm{N}, 84.4^{\circ} \mathrm{E}$ & Graywackes & $\begin{array}{l}\mathrm{C} 1 \mathrm{x} \\
(\mathrm{P} 2)\end{array}$ & $341 / 85$ & $7 / 10$ & $\mathrm{R}$ & 213.8 & -61.3 & 233.2 & 17.7 & 204.3 & 4.2 \\
\hline \multirow[t]{2}{*}{ Mean } & & & & & 5 & $\mathbf{R}$ & 212.7 & -57.6 & & & 196.9 & 5.5 \\
\hline & & & & & & & & & 229.8 & 18.4 & 217.8 & 5.2 \\
\hline
\end{tabular}

Table 1 


\begin{tabular}{|c|c|c|c|c|c|c|c|c|c|c|c|c|}
\hline Bloc & Locality & Age & $\mathbf{N}$ & $\begin{array}{l}\text { Slat } \\
\left({ }^{\circ}\right)\end{array}$ & $\begin{array}{c}\text { Slong } \\
\left({ }^{\circ}\right)\end{array}$ & $\begin{array}{l}\text { Plat } \\
\left({ }^{\circ}\right)\end{array}$ & $\begin{array}{l}\text { Plong } \\
\left({ }^{\circ}\right)\end{array}$ & $\begin{array}{l}\mathrm{A} 95 \\
\left({ }^{\circ}\right)\end{array}$ & $\begin{array}{l}\text { dp } \\
\left({ }^{\circ}\right)\end{array}$ & $\begin{array}{c}\mathrm{dm} \\
\left({ }^{\circ}\right)\end{array}$ & $\begin{array}{c}\# \\
\text { REF }\end{array}$ & REF \\
\hline \multirow[t]{9}{*}{ S Junggar } & Urumqi a* & $\mathrm{C} 2$ & 7 & 43.8 & 87.8 & 54.6 & 173.5 & 14.0 & 11.9 & 16.5 & 1 & Li et al., 1991 \\
\hline & Urumqi $a^{*}$ & $\mathrm{C} 2$ & 6 & 43.8 & 87.8 & 73.4 & 96.5 & 27.4 & 26.1 & 28.9 & 2 & Li et al., 1991 \\
\hline & Urumqi & C3 & 15 & 43.8 & 87.8 & 71.9 & 4.7 & 13.3 & 11.7 & 15.1 & 3 & Li et al., 1991 \\
\hline & Urumqi & P1 & 4 & 43.8 & 87.8 & 79.5 & 36.6 & 6.8 & 6.2 & 7.5 & 4 & THIS STUDY \\
\hline & Urumqi & $\mathrm{P} 2$ & 6 & 43.8 & 87.8 & 60.4 & 4.7 & 5.4 & 4.7 & 6.3 & 5 & THIS STUDY \\
\hline & Urumqi b & $\mathrm{P} 2$ & $78 s$ & 43.8 & 87.7 & 77.7 & 0.5 & 5.5 & 4.8 & 6.2 & 6 & Sharps et al., 1992 \\
\hline & Urumqi & $\mathrm{P} 2$ & 4 & 43.8 & 87.7 & 75.0 & 13.3 & 22.1 & 19.8 & 24.8 & 7 & Sharps et al., 1992 \\
\hline & Tien Shi c & $\mathrm{P} 2$ & 6 & 44.0 & 88.1 & 83.6 & 211.8 & 7.7 & 6.6 & 8.9 & 8 & Nie et al., 1993 \\
\hline & Mean & C3 to P2 & 6 & & & 77.0 & 7.6 & 9.9 & & & & \\
\hline \multirow[t]{10}{*}{ W Junggar } & Karamay d* & C3-P & 2 & 45.3 & 84.3 & 62.7 & 182.6 & - & - & - & 9 & Zhao et al., 1990 \\
\hline & Karamay & $\begin{array}{l}\text { C3-P } \\
\text { OVP }\end{array}$ & 9 & 45.5 & 84.4 & 65.3 & 329.7 & 6.3 & 5.2 & 7.7 & 10 & THIS STUDY \\
\hline & Hoboksar & C2-P & 11 & 47.2 & 86.6 & 67.3 & 345.2 & 7.5 & 6.4 & 8.7 & 11 & Li et al., 1991 \\
\hline & Hoboksar & $\mathrm{C} 2$ & 13 & 46.7 & 86.1 & 69.2 & 302.7 & 5.6 & 4.5 & 6.9 & 12 & Li et al., 1991 \\
\hline & Mean & C2-P & 3 & & & 68.2 & 326.7 & 12.6 & & & & \\
\hline & Karamay d* & P2 & 25 & 45.6 & 83.2 & 78.0 & 238.7 & 7.9 & 6.6 & 9.4 & 13 & Li et al., 1989 \\
\hline & Karamay & $\mathrm{P} 2$ & 10 & 45.6 & 84.2 & 46.5 & 189.8 & 26.6 & 20.7 & 34.3 & 14 & Zhao et al., 1990 \\
\hline & Karamay & P2 OVP & 12 & 45.5 & 84.7 & 47.6 & 180.6 & 7.8 & 6.3 & 9.7 & 15 & Zhao et al., 1990 \\
\hline & Karamay & P2 OVP & 5 & 45.5 & 84.4 & 64.8 & 179.5 & 6.9 & 5.9 & 8.1 & 16 & THIS STUDY \\
\hline & Mean & P2 & 3 & & & 53.0 & 183.9 & 16.6 & & & & \\
\hline \multirow[t]{9}{*}{$\begin{array}{c}\text { NE } \\
\text { Kazakhstan }\end{array}$} & Ayaguz A & C3-P & 15 & 47.85 & 80.0 & 13.3 & 138.3 & 6.9 & 5.7 & 8.4 & 17 & $\begin{array}{l}\text { Abrajevitch et al., } \\
2008\end{array}$ \\
\hline & Tokrau A & C3-P & 18 & 48.1 & 75.6 & 42.2 & 178.8 & 4.0 & 3.1 & 5.2 & 18 & $\begin{array}{l}\text { Abrajevitch et al., } \\
2008\end{array}$ \\
\hline & $\begin{array}{c}\text { Ayaguz A } \\
\mathrm{e}^{\star}\end{array}$ & P1 & 8 & 47.8 & 80.0 & 25.6 & 151.2 & 4.3 & 6.4 & 5.3 & 19 & $\begin{array}{l}\text { Levashova et al., } \\
2003 b\end{array}$ \\
\hline & Chingiz & P OVP & 9 & 48.8 & 79.0 & 42.0 & 157.0 & 12.9 & 11.0 & 15.2 & 20 & Collins et al., 2003 \\
\hline & Chingiz $f^{*}$ & P2 OVP & 16 & 48.4 & 78.4 & 55.4 & 135.4 & 6.6 & 6.2 & 7.1 & 21 & $\begin{array}{l}\text { Levashova et al., } \\
2003 a\end{array}$ \\
\hline & Ayaguz B & $\mathrm{P} 2$ & 11 & 47.8 & 80.0 & 48.5 & 172.2 & 11.5 & 9.5 & 13.9 & 22 & $\begin{array}{l}\text { Abrajevitch et al., } \\
2008\end{array}$ \\
\hline & Tokrau B & P2 & 19 & 47.9 & 75.3 & 56.3 & 180.6 & 4.5 & 3.7 & 5.5 & 23 & $\begin{array}{l}\text { Abrajevitch et al., } \\
2008\end{array}$ \\
\hline & Ayaguz B & $\mathrm{P} 2$ & 8 & 47.6 & 79.7 & 42.8 & 171.6 & 3.6 & 2.9 & 4.4 & 24 & $\begin{array}{l}\text { Levashova et al., } \\
2003 b\end{array}$ \\
\hline & Mean & P2 & 5 & & & 46.6 & 171.6 & 8.4 & & & & \\
\hline \multirow[t]{2}{*}{ Siberia } & Mean & $\mathrm{C2}$ & 17 & & & 41.0 & 169.0 & 3.0 & & & & Van der Voo. 1993 \\
\hline & Mean & P2 & 5 & & & 50.0 & 160.0 & 7.0 & & & & Van der Voo. 1993 \\
\hline \multirow[t]{2}{*}{ Tarim } & Mean & $\mathrm{C2}$ & 6 & & & 51.5 & 169.1 & 7.7 & & & & Wang et al., 2007 \\
\hline & Mean & P2 & 5 & & & 66.8 & 184.1 & 4.9 & & & & Wang et al., 2007 \\
\hline \multirow[t]{2}{*}{ Yili } & Mean & $\mathrm{C2}$ & 2 & & & 68.6 & 290.6 & 6.1 & & & & Wang et al., 2007 \\
\hline & Mean & P2 & 1 & & & 79.7 & 172.0 & 11.3 & & & & Wang et al., 2007 \\
\hline
\end{tabular}




\begin{tabular}{ccccc}
\hline Period & Blocks & $\begin{array}{c}\text { ANG } \pm \\
\text { DANG }\end{array}$ & $\begin{array}{c}\text { ROT } \pm \\
\text { DROT }\end{array}$ & $\begin{array}{c}\text { Plat } \pm \\
\text { DPlat }\end{array}$ \\
\hline C2-P & WJG - & $14.6^{\circ} \pm$ & $-4.4^{\circ} \pm$ & $14.2^{\circ} \pm$ \\
& SJG & $16.0^{\circ}$ & $16.2^{\circ}$ & $10.0^{\circ}$ \\
& WJG - & $98.3^{\circ} \pm$ & $-130.1^{\circ} \pm$ & $1.6^{\circ} \pm$ \\
& NKZ & $14.4^{\circ}$ & $13.3^{\circ}$ & $9.0^{\circ}$ \\
& WJG - & $69.5^{\circ} \pm$ & $-84.4^{\circ} \pm$ & $-1.9^{\circ} \pm$ \\
& SIB & $13.0^{\circ}$ & $12.0^{\circ}$ & $8.1^{\circ}$ \\
& SJG - & $61.4^{\circ} \pm$ & $-80.3^{\circ} \pm$ & $-12.1^{\circ} \pm$ \\
& SIB & $10.3^{\circ}$ & $11.2^{\circ}$ & $6.5^{\circ}$ \\
& SJG - & $51.0^{\circ} \pm$ & $-69.1^{\circ} \pm$ & $7.0^{\circ} \pm$ \\
& TAR & $12.5^{\circ}$ & $13.3^{\circ}$ & $7.8^{\circ}$ \\
& SJG - YI & $22.2^{\circ} \pm$ & $-9.3^{\circ} \pm$ & $-20.9^{\circ} \pm$ \\
& & $11.6^{\circ}$ & $12.0^{\circ}$ & $7.3^{\circ}$ \\
\hline P2 & WJG - & $50.0^{\circ} \pm$ & $61.7^{\circ} \pm$ & $17.2^{\circ} \pm$ \\
& SJG & $19.3^{\circ}$ & $18.7^{\circ}$ & $12.1^{\circ}$ \\
& WJG - & $10.2^{\circ} \pm$ & $-11.4^{\circ} \pm$ & $2.8^{\circ} \pm$ \\
& NKZ & $18.6^{\circ}$ & $16.8^{\circ}$ & $11.6^{\circ}$ \\
& WJG - & $15.0^{\circ} \pm$ & $-12.5^{\circ} \pm$ & $11.2^{\circ} \pm$ \\
& SIB & $18.0^{\circ}$ & $16.5^{\circ}$ & $11.2^{\circ}$ \\
& WJG - YI & $27.0^{\circ} \pm$ & $28.5^{\circ} \pm$ & $15.1^{\circ} \pm$ \\
& & $20.1^{\circ}$ & $19.4^{\circ}$ & $12.6^{\circ}$ \\
& WJG - & $13.8^{\circ} \pm$ & $13.9^{\circ} \pm$ & $7.5^{\circ} \pm$ \\
& TAR & $17.3^{\circ}$ & $15.7^{\circ}$ & $10.8^{\circ}$ \\
\hline
\end{tabular}

Table 3 


\begin{tabular}{crrcr}
\hline Blocks (age) & \multicolumn{2}{c}{$\begin{array}{c}\text { Euler Pole Radius } \\
\text { coordinates }\end{array}$} & $\begin{array}{r}\text { Modulus of rotation angle } \\
\text { with errors }\end{array}$ & $\begin{array}{r}\text { Diplacement with } \\
\text { errors }\end{array}$ \\
\hline YIL/TAR (P2) & $54^{\circ} \mathrm{N}, 76^{\circ} \mathrm{E}$ & $\begin{array}{r}1690 \\
\mathrm{~km}\end{array}$ & $14^{\circ} \pm 12.9^{\circ}$ & $410 \pm 380 \mathrm{~km}$ \\
SJG/YIL (P2) & $50^{\circ} \mathrm{N}, 92^{\circ} \mathrm{E}$ & $880 \mathrm{~km}$ & $32^{\circ} \pm 16.4^{\circ}$ & $490 \pm 250 \mathrm{~km}$ \\
SJG/SIB (P2) & $56^{\circ} \mathrm{N}, 101^{\circ} \mathrm{E}$ & 1220 & $73.9^{\circ} \pm 13.1^{\circ}$ & $1570 \pm 280 \mathrm{~km}$ \\
& & $\mathrm{~km}$ & & \\
SJG/SIB (C2 to & $56^{\circ} \mathrm{N}, 101^{\circ} \mathrm{E}$ & 1220 & $6.4^{\circ} \pm 11.7^{\circ}$ & $140 \pm 250 \mathrm{~km}$ \\
P2) & & $\mathrm{km}$ & & \\
\hline
\end{tabular}

Table

4 